\title{
Identification of a Survival-Promoting Peptide in Medium Conditioned by Oxidatively Stressed Cell Lines of Nervous System Origin
}

\author{
Timothy J. Cunningham, ${ }^{1}$ Lisa Hodge, ${ }^{1}$ David Speicher, ${ }^{2}$ Dave Reim, ${ }^{2}$ Carla Tyler-Polsz, ${ }^{1}$ Pat Levitt, ${ }^{1}$ \\ Kathie Eagleson, ${ }^{1}$ Sarah Kennedy, ${ }^{1}$ and Ying Wang ${ }^{1}$ \\ ${ }^{1}$ Department of Neurobiology and Anatomy, Allegheny University of the Health Sciences, Philadelphia, Pennsylvania \\ 19129, and 2The Wistar Institute of Anatomy and Biology, Philadelphia, Pennsylvania 19104
}

A survival-promoting peptide has been purified from medium conditioned by $\mathrm{Y} 79$ human retinoblastoma cells and a mouse hippocampal cell line ( $\mathrm{HN} 33.1$ ) exposed to $\mathrm{H}_{2} \mathrm{O}_{2}$. A 30 residue synthetic peptide was made on the basis of $\mathrm{N}$-terminal sequences obtained during purification, and it was found to exhibit gel mobility and staining properties similar to the purified molecules. The peptide maintains cells and their processes in vitro for the $\mathrm{HN} 33.1$ cell line treated with $\mathrm{H}_{2} \mathrm{O}_{2}$, and in vivo for cortical neurons after lesions of the cerebral cortex. It has weak homology with a fragment of a putative bacterial antigen and, like that molecule, binds IgG. The peptide also contains a motif reminiscent of a critical sequence in the catalytic region of calcineurin-type phosphatases; surprisingly, like several members of this family, the peptide catalyzes the hydrolysis of para-nitrophenylphosphate in the presence of $\mathrm{Mn}^{2+}$. Application of the peptide to one side of bilateral cerebral cortex lesions centered on area 2 in rats results in an increase in IgG immunoreactivity in the vicinity of the lesions $7 \mathrm{~d}$ after surgery. Microglia immunopositive for IgG and ED-1 are, however, dramatically reduced around the lesions in the treated hemisphere. Furthermore, pyramidal neurons that would normally shrink, die, or disintegrate were maintained, as determined by MAP2 immunocytochemistry and Nissl staining. These survival effects were often found in both hemispheres. The results suggest that this peptide operates by diffusion to regulate the immune response and thereby rescue neurons that would usually degenerate after cortical lesions. The phosphatase activity of this molecule also suggests the potential for direct neuron survivalpromoting effects.

Key words: peptide; neuron survival; immune evasion; microglia; lgG; phosphatase
The search for agents that affect neuron survival has intensified in recent years because of increased interest in the etiology and treatment of several neurodegenerative disorders. These efforts have now focused on the role of oxidative stress in neuronal degeneration because destructive oxygen free radicals are implicated in a variety of neuropathological conditions. For example, neuron death or rescue resulting from trauma, altered neurotransmitter levels, $\beta$-amyloid toxicity, neurohormone treatment, and neurotrophic factor treatment or deprivation all can be related to the production or sequestering of reactive oxygen species (for review, see Coyle and Puttfarcken, 1993; Mattson et al., 1993; Gotz, 1994; Greenlund et al., 1995; Beal, 1995; Davis, 1996; Mark et al., 1996; Yankner, 1996; Furukawa et al., 1997). This is also the case for the death of many non-neuronal cell types that degenerate under a variety of conditions. One interesting aspect of the response to oxidative insult is that some of these cell types

\footnotetext{
Received March 16, 1998; revised June 4, 1998; accepted June 24, 1998.

Supported by the National Institutes of Health Grant NS16487. We thank Dr. Itzhak Fischer, Don Faber, and Brian Balin for valuable advice and encouragement during the course of this study. We also thank Dr. Robert Nichols, who advised us in the phosphatase experiments. Dr. Karl Hellstrom read a version of this manuscript, and we are grateful for his comments.

Correspondence should be addressed to Dr. Timothy Cunningham, Department of Neurobiology and Anatomy, Allegheny University of the Health Sciences, 3200 Henry Avenue, Philadelphia, PA 19129.

Dr. Levitt's and Dr. Eagleson's present address: Department of Neurobiology, 3500 Terrace Street, University of Pittsburgh School of Medicine, Pittsburgh, PA 15261.

Copyright (ㄷ) 1998 Society for Neuroscience $\quad 0270-6474 / 98 / 187047-14 \$ 05.00 / 0$
}

may adapt to this stress by the production of protective agents that limit the extent of cell death from subsequent attacks. This conditioning effect has been demonstrated in several cell lines and is presumably related to the production of survival-promoting factors by these cells (Crawford and Davies, 1994; Davies et al., 1995; Wiese et al., 1995). The purpose of this study was to determine whether such an agent could be identified in cell lines that are derived from the nervous system and then applied to cerebral cortex lesions to aid in the repair of damaged cortical tissue. This paper describes the steps leading to the identification and synthesis of a survival-promoting peptide that is present in medium conditioned by two cell lines treated with hydrogen peroxide. The amino acid sequence of this peptide has few significant alignments in the protein database but is similar at the $\mathrm{N}$ terminus to a fragment of a putative bacterial antigen that binds Ig. It also has a small motif that is reminiscent of a critical sequence in the catalytic portion of calcineurin-type phosphatases. We show both IgG binding and phosphatase activity for this peptide and suggest that these properties are related to its survival-promoting activity.

\section{MATERIALS AND METHODS}

Conditioned medium preparation. The peptide was purified from medium conditioned by human Y79 retinoblastoma cells (American Type Culture Collection, Manassas, VA) and a mouse hippocampal cell line (HN 33.1) that was a gift of Dr. Bruce Wainer (Lee et al., 1990). The retinoblastoma cell line is derived from the photoreceptor layer, and the hippocampal line is a hybrid of postnatal hippocampal cells and neuro- 
Table 1. Summary of activity of purified fractions and synthetic peptide in HN cell assay

\begin{tabular}{lccc} 
Source & Experiments & $\begin{array}{l}\text { Concentration tested } \\
\text { (ng/ml) }\end{array}$ & $\begin{array}{l}\text { Effective concentration } \\
(\mathrm{ng} / \mathrm{ml})\end{array}$ \\
\hline Y79 fraction 1 size exclusion & 2 & $0.1-1000$ & $0.1-1000$ \\
Y79 fraction 2 size exclusion & 3 & $0.1-1000$ & $10-1$ \\
Y79 fraction 3 size exclusion & 2 & $0.1-1000$ & $1-0.1$ \\
Y79 17 kDa gel eluent & 3 & $0.1-1000$ & $1-0.1$ \\
Y79 12 kDa gel eluent & 2 & $10^{-12}-1000$ & $10^{-3}-10^{-7}$ \\
HN 33.1 cation exchange/hydrophobic interaction & 12 & $10^{-12}-1000$ & $10^{-3}-10^{-6}$ \\
HN 33.1 6-8 kDa gel eluent & 17 & $10^{-12}-1000$ & $1-10^{-3}$ \\
Synthetic peptide YDP & 5 & $10^{-12}-1000$ &
\end{tabular}

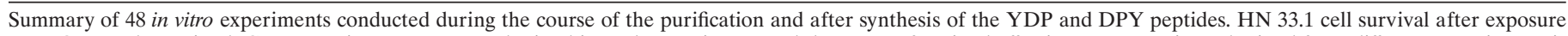

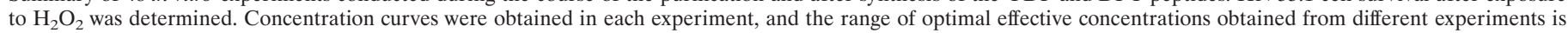
shown. Effective concentrations resulted in at least a twofold increase in HN 33.1 cells with processes compared with DMEM vehicle controls.

blastoma N18TG2. Both cell lines were first grown in $100 \mathrm{~mm}$ uncoated plastic dishes in DMEM supplemented with $15 \%$ fetal bovine serum. All DMEM solutions were treated with antibiotic and antimycotic solution (penicillin, streptomycin, and amphotericin B at $10 \mathrm{ml} / \mathrm{l}$; Sigma, St. Louis, MO). The cells were transferred to $80 \mathrm{~cm}^{2}$ culture flasks for $3 \mathrm{~d}$, and DMEM was added over this period to bring the total volume of medium to $30 \mathrm{ml}$ per flask. The cells continued to divide and reached an estimated $5 \times 10^{7}$ cells per flask before treatment with $\mathrm{H}_{2} \mathrm{O}_{2}$. The cultures were terminated after exposure to $0.1 \% \mathrm{H}_{2} \mathrm{O}_{2}$ for $30 \mathrm{~min}$, and the entire volume of the $3 \mathrm{~d}$ conditioned medium (CM) was collected. The CM was centrifuged to remove floating cells, prefiltered through Whatman No. 50 paper (Maidstone, UK), and was filtered finally through a $0.22 \mu \mathrm{m}$ bottle top filter.

Purification. For the Y79 retinoblastoma cells, $500-1000 \mathrm{ml}$ of the medium was used as starting material for each purification. The medium was concentrated to $10-20 \mathrm{ml}$ through concentrators with a $10 \mathrm{kDa}$ cutoff (Amicon, Beverly, MA) and dialyzed for at least $24 \mathrm{hr}$ against several changes of $50 \mathrm{~mm} \mathrm{HCl}$. The sample was concentrated again to $1 \mathrm{ml}$ and dialyzed overnight against $\mathrm{HCl}$. Dialysis membranes with a $3.5 \mathrm{kDa}$ cutoff were used for the retinoblastoma CM purification. This and all subsequent dialysis steps were conducted against a 1000-fold excess volume at $4^{\circ} \mathrm{C}$. The sample was then loaded onto a mono $\mathrm{S}$ column (Pharmacia, Piscataway, NJ) and eluted at $1 \mathrm{ml} / \mathrm{min}$ by HPLC (Peptide Mapping System; Perkin-Elmer, Norwalk, CT) in $3 \mathrm{~mm} \mathrm{HCl,} \mathrm{pH} \mathrm{2.5.}$ The void peak (starting state elution) was collected. The sample was dialyzed in diluted $\mathrm{HCl}$ and reconstituted for gel filtration in $50 \mathrm{mM} \mathrm{HCl}$ on a Superose 12 column at $0.3 \mathrm{ml} / \mathrm{min}$. Activity in the $\mathrm{HN}$ cell assay was detected in a 54-57 min fraction (Table 1, fraction 2). It was collected and dialyzed in preparation for gel electrophoresis. Preparative SDS gels were run as described below, and 12 and $17 \mathrm{kDa}$ bands were cut from these gels and homogenized in $1 \mathrm{ml}$ PBS for biological testing. After 24 $\mathrm{hr}$, the samples were filtered and dialyzed against two changes of PBS for $24 \mathrm{hr}$. Total protein concentration, estimated using the BCA kit from Pierce (Rockford, IL), were between 500 and $700 \mu \mathrm{g} / \mathrm{ml}$ before gel filtration. Based on the same assay, sample concentration was between $1-10 \mu \mathrm{g} / \mathrm{ml}$ for all subsequent steps.

For the HN cells additional steps were used, because these cells, which readily adhere to tissue culture plastic and grow processes, apparently secrete large quantities of extracellular matrix material. The fraction containing this material had to be first isolated (because of charge similarities to the peptide of interest) and then separated. This was accomplished with additional chromatography steps and stronger $\mathrm{HCl}$. The $\mathrm{H}_{2} \mathrm{O}_{2}$-treated CM (1000-1200 ml) was lyophilized and redissolved in $\sim 20 \mathrm{ml}$ of Milli-Q water. (For one of the purifications, $500 \mathrm{ml}$ of $\mathrm{CM}$ was from cells treated with $\mathrm{H}_{2} \mathrm{O}_{2}$, and the other $500 \mathrm{ml}$ was untreated to test for the effect of the peroxide on recovery of the gel bands of interest; see Fig. $1 B$ and Results.) The samples were dialyzed for $48 \mathrm{hr}$ against three changes of 161 of $25 \mathrm{~mm}$ Tris, $\mathrm{pH} 7.5$, using membranes with a 1 $\mathrm{kDa}$ cutoff. Initial separations were via $7-15$ runs with a high-load Sepharose-Q column (Pharmacia), at $2 \mathrm{ml} / \mathrm{min}$ in the Tris buffer (A) with a 20 min gradient to $100 \% \mathrm{~B}$ (Tris $+1 \mathrm{M} \mathrm{NaCl}$ ). The final peak from this column (most negatively charged) was collected at $45 \mathrm{~min}$ and pooled from the different runs. This sample was dialyzed for $12-18 \mathrm{hr}$ against three changes of 1000 -fold excess of $\mathrm{HCl}$, then water, and reconstituted in $0.2 \mathrm{M} \mathrm{HCl}$ for cation exchange as above followed by dialysis for preparative electrophoresis. Samples with high absorbance at $280 \mathrm{~nm}$ (indicative of impurities containing primarily tryptophan) were dried and redissolved in $20 \mathrm{~mm} \mathrm{HCl}$ for loading on a C18 column (Nest Group, Southborough, MA) before the electrophoresis step. The void was collected and treated as above. A prominent $5-8 \mathrm{kDa}$ band was cut from the preparative gels and eluted and dialyzed as described above (see Fig. $1 B)$. The mono $\mathrm{S}$ and $\mathrm{C} 18$ columns were reconstituted with $\mathrm{NaCl}$ and acetonitrile gradients, respectively, and cleaned frequently following the manufacturer's suggestions.

Gel electrophoresis, peptide transfer, and amino acid sequencing. Polyacrylamide minigels $(0.75 \mathrm{~mm}$ thick $)$ with $0.1 \%$ SDS were cast by standard procedures or purchased from Bio-Rad (Hercules, CA) without SDS. Preparative gels were $1.5 \mathrm{~mm}$ thick. The sample buffer was $0.1 \mathrm{M}$ Tris, pH 6.8, and included glycerol, EDTA, bromophenol blue, and $0.5 \%$ SDS. For reducing gels, $2 \%$ SDS was used along with $2 \mathrm{mg} / \mathrm{ml}$ DTT in the sample buffer. Running buffer was Tris-tricine, $\mathrm{pH}$ 8. The gels were run at $58 \mathrm{~V}$ for $15 \mathrm{~min}$, then at $160 \mathrm{~V}$ for $1 \mathrm{hr}$. The gels were stained with Coomassie blue, silver reagent, or the protein "Quick Stain" (Zoion, Newton, MA). Quick Stain was used according to the supplier's protocol and applied when bands were to be eluted and then tested for biological activity, chromatographed further, or rerun on SDS gels. Gels with sample buffer only lanes were routinely stained with these methods to check for contaminated reagents. Proteins were transferred from the gel to PVDF membranes for amino acid sequencing using a Tris-glycine buffer containing $10 \%$ methanol and $0.01 \%$ SDS. Transfer was for $2 \mathrm{hr}$ at a constant $250 \mathrm{~mA}$. N-terminal sequences were determined from amido black-stained blots with a Hewlett Packard G1005A sequencer as described previously (Reim and Speicher, 1994). Resulting sequences were compared with known sequences in the composite protein database provided by National Center for Biotechnology Information, and computations were performed using the BLAST network service (Altschul et al., 1994). Synthetic and scrambled peptides, made subsequently (see below), were transferred from reducing gels to nitrocellulose paper under the same conditions to test for capture of IgG. After blocking the blots in $5 \%$ dry milk, they were incubated for $1 \mathrm{hr}$ in $2.5 \mu \mathrm{g} / \mathrm{ml}$ whole mouse $\mathrm{IgG}$ (Sigma). The blots were washed extensively and immunostained for mouse $\operatorname{IgG}$ with a polyclonal antibody raised in rabbits (Sigma) and a goat anti-rabbit secondary antibody conjugated to HRP (Fisher Scientific, Pittsburgh, PA). Blots were developed with 4-chloronapthol as the chromogen.

Synthetic peptide. Synthetic peptides based on the sequence of the purified peptides were prepared by Primm Labs (Kendall Square, MA) and by the Protein Chemistry Lab at the University of Pennsylvania. A scrambled peptide based on this sequence was also prepared. The peptides were purified on a C18 column followed by drying and reconstitution twice. Mass spectroscopy of the peptides gave single peaks at $\sim 3000$ $\mathrm{Da}$. They were dissolved in water, and aliquots were frozen at $-80^{\circ} \mathrm{C}$ until use. The concentration of the peptide used for individual experiments was determined by its measured weight. The BCA assay underestimated by threefold the actual concentration of the synthetic 
peptide; similar inaccuracies likely pertain to protein estimates during purification.

In vitro assay. HN cells were placed in individual wells $(90,000$ per well) of microwell plates and grown overnight in DMEM containing $7.5 \%$ fetal bovine serum. The $\mathrm{NaHCO}_{3}$ in all DMEM solutions was adjusted so concentration was appropriate for a $\mathrm{pH}$ of 7.4 in a $5 \% \mathrm{CO}_{2}$ atmosphere (Dawson et al., 1986). The wells were coated with $0.5 \mathrm{mg} / \mathrm{ml}$ collagen (type IV; Sigma). Rows or columns of the plates projected to contain the various experimental and control groups were randomized, and the identity of the groups was unfamiliar to the investigator scoring the wells. The cultures were treated with $0.03 \% \mathrm{H}_{2} \mathrm{O}_{2}$ for $10-20 \mathrm{~min}$, after which the medium was changed to serum-free DMEM for $20 \mathrm{~min}$. The medium was changed again to DMEM-containing peptide, or purified fractions, at various dilutions. Controls included a DMEM control and a DMEM control that had the same medium changes but no $\mathrm{H}_{2} \mathrm{O}_{2}$. The cultures were terminated after $4 \mathrm{hr}$ by fixation for $15 \mathrm{~min}$ in phosphate-buffered paraformaldehyde treated with $0.1 \%$ Triton X-100 for 5 min before immunostaining with a polyclonal antibody to actin (Sigma). The secondary antibodies were HRP-conjugated. Viable multipolar cells were defined as having a nucleus and two or more processes with one well-defined process at least as long as the nucleus. These were counted in systematically defined fields that encompassed at least $25 \%$ of the culture well. The comparisons made in these experiments were always between DMEM (vehicle) controls and various concentrations of peptide diluted with DMEM. Active fractions were identified during purification by at least twofold increases over controls with statistical significance.

In vivo assay. Thirty-two male Long-Evans hooded rats (300-350 gm) were used in the in vivo studies. Twenty-five of these animals received large bilateral lesions of the cerebral cortex. The animals were deeply anesthetized with ketamine and xylazine $(100 / 5 \mathrm{mg} / \mathrm{kg})$, and surgery was performed under aseptic conditions. Symmetrical bilateral skull openings were made $4 \mathrm{~mm}$ caudal to bregma along the ridge that marks the insertion of the temporalis muscle. The lesions were made by suction down to and including some white matter. Gelfoam saturated with either the peptide or DMEM vehicle was inserted into the lesion cavity. The synthetic peptide was delivered unilaterally at either $100 \mu \mathrm{M}$ (eight rats) or $200 \mu \mathrm{M}$ (four rats). Five rats had similar lesions, but DMEM was delivered to both hemispheres. Four rats were unoperated. Animals with extensive subcortical damage or gross lesion asymmetry were not used and were not included in these totals. Eleven additional rats (eight treated, three controls) had similar lesions and were treated with peptide purified from HN 33.1 CM in a more limited study of ED-1-positive microglia cells. The estimated concentration of purified peptide used in these experiments was $3 \mu \mathrm{g} / \mathrm{ml}$. Rats with lesions survived for $7 \mathrm{~d}$, after which they received an overdose of Nembutal and were perfused through the left ventricle with phosphate-buffered paraformaldehyde. Brains were immersed in $30 \%$ sucrose-buffer from 1 to $2 \mathrm{~d}$, after which serial sections $60 \mu \mathrm{m}$ thick were cut on a sliding microtome.

Alternate sections were immunostained for rat IgG using polyclonals to whole rat IgG (Sigma) and to MAP2 (a gift from Dr. Itzhak Fischer), and were stained with the Nissl method for cell bodies. All experimental groups were processed in batches together. Quantitative comparisons of peptide-treated and vehicle-treated hemispheres were done on coded slides and in the same sections for all of the quantitative procedures to further control for processing differences between sections. The depth, rostral caudal extent, surviving medial segment, and surviving lateral segments of the hemispheres were estimated from planimetric measurements on equally spaced Nissl-stained sections through the lesion site. Serial sections immunostained for MAP2 and spaced at $0.33 \mathrm{~mm}$ through the extent of the lesion were each scored for the existence of neurons in surviving area 2 with either secondary or tertiary dendritic branches. Total MAP2-immunopositive cell bodies with at least one dendrite were counted in pyramidal layers III and V of the medial surviving segment at two levels through the lesion, and their density was determined. Pyramidal cell areas in layer $\mathrm{Vb}$ at the medial border of area 3 were measured in Nissl-stained sections. Fields from two sections (total area $=0.073$ $\mathrm{mm}^{2}$ ) at the level of the bifurcation of the fimbria-rostral hippocampus were captured and digitized (see below). Areas of cells with apical processes that fell on intersections of an overlay grid were measured by tracing around their perimeters. Measurements from $>800$ cells were made (at least 40 cells per brain). Standardization of the region selected for the counts, as well as of histological processing, was achieved using specific cytoarchitectonic criteria (see Results) and by the fact that the counts were from the same section at a similar coronal levels. Microglial cell bodies that were connected to ramified processes and immunopositive for IgG were also counted and compared in single sections of treated and untreated hemispheres through the midpoint of the lesion. The counts were made where microglial cells were consistently most concentrated in control animals with lesions, i.e., within the white matter and overlying deep cortical layers at the medial border of the lesion. Sections from the eight animals that received the HN 33.1 CM-purified peptide or three controls done specifically with this group were immunostained with a mouse monoclonal antibody to ED-1 (Accurate Chemical, Westbury, NY) as in previous studies (Milligan et al., 1991), and analyzed similarly. All other antibodies applied in vivo were polyclonal and raised in rabbits. The anti-IgG and anti-MAP2 were both used at a dilution of 1:200. They were visualized by goat anti-rabbit secondary antibody conjugated to HRP, which was unreactive in tissue sections at the dilution used (1:100). Quantification and photography were assisted by capturing images on a DMRB microscope with a DC-330 CCD color camera (DAGE-MTI, Michigan City, IN). Images from single sections were contrasted together and analyzed with IP Laboratories Spectrum software (Signal Analytics, Vienna, VA). All micrographs showing both sides of the brain in this paper are from the same brain section.

Hydrolysis of para-nitrophenylphosphate. The ability of the synthetic peptides to catalyze the hydrolysis of para-nitrophenylphosphate ( $p$ NPP; Calbiochem, La Jolla, CA) was tested in microwells at room temperature. The peptides were mixed with reaction buffer, and $100 \mu$ l of this mixture was added to microwells containing $50 \mu \mathrm{l}$ substrate solution. The final concentration of $p$-NPP was 1 or $2 \mathrm{~mm}$. The reaction buffer consisted of $3 \mathrm{~mm} \mathrm{MnCl}$ and $1 \mathrm{mM} \mathrm{ZnCl}_{2}$ in $50 \mathrm{~mm}$ Tris- $\mathrm{HCl}, \mathrm{pH} 8.5$. These conditions were varied in some experiments to test metal ion dependency. In other experiments, sodium orthovanadate (Calbiochem) was mixed with the peptide solution at $30 \mu \mathrm{M}$ to inhibit phosphatase activity. After substrate baseline measurements, absorbance at $405 \mathrm{~nm}$ was monitored relative to reaction buffer blanks at various times between 4 and $60 \mathrm{~min}$ after initiation of the reaction. Each time point in individual experiments was mean and SEM of four reaction wells for all conditions.

All statistical analyses in this study were made using InStat software (GraphPad, San Diego, CA). Significant levels were obtained from twotailed Mann-Whitney $U$ tests or linear regression analysis.

\section{RESULTS}

\section{Identification of the survival-influencing peptide in CM}

The purification procedures and biological assay were based on preliminary observations of an acid-stable, proteolysis-resistant, and concentration-dependent survival factor present in medium conditioned by both nervous system cell lines and embryonic cortical neurons (our unpublished observations) (Eagleson et al., 1990, 1992; Haun and Cunningham, 1993). The peptide was initially isolated from medium conditioned by $\mathrm{H}_{2} \mathrm{O}_{2}$-treated $\mathrm{Y} 79$ retinoblastoma cells, and a similar peptide was detected in $\mathrm{HN}$ 33.1 CM. The purification procedures that led to the isolation of this peptide were similar but not identical for these two cell lines (Fig. $1 A$; see Materials and Methods). Table 1 presents a summary of the assay experiments that lead to identification of the active fractions and gel bands following the intermediate chromatography steps and finally preparative electrophoresis. For the HN 33.1 CM, activity was found in a diffuse 5-8 kDa band after the electrophoresis step. Importantly, this band was markedly exaggerated by $\mathrm{H}_{2} \mathrm{O}_{2}$ treatment of the cells (Fig. $1 B$ ). For the Y79 cells, active gel eluents were found at 12 and $17 \mathrm{kDa}$ after gel filtration (Fig. 1C). N-terminal sequencing of the $17 \mathrm{kDa}$ band derived from Y79 CM gave the following: X-Asp-Pro-Glu-Ala Ala-Ser-Ala-Pro-Gly Ser-Gly-Asn-Pro-(Cys) His-Glu-Ala-SerAla Ala-Gln-X-Glu-Asn Ala-Gly-(Glu)-Asp-Pro; X indicates a residue that was ambiguous or not detected; residues in parentheses indicate tentative assignment.

A similar sequence was detected in both 14 and $17 \mathrm{kDa}$ bands that were recovered from $\mathrm{HN} 33.1 \mathrm{CM}$ after rerunning the eluted 5-8 kDa band (Fig. 1C). It included residues 2-18, as the peptide 
A.

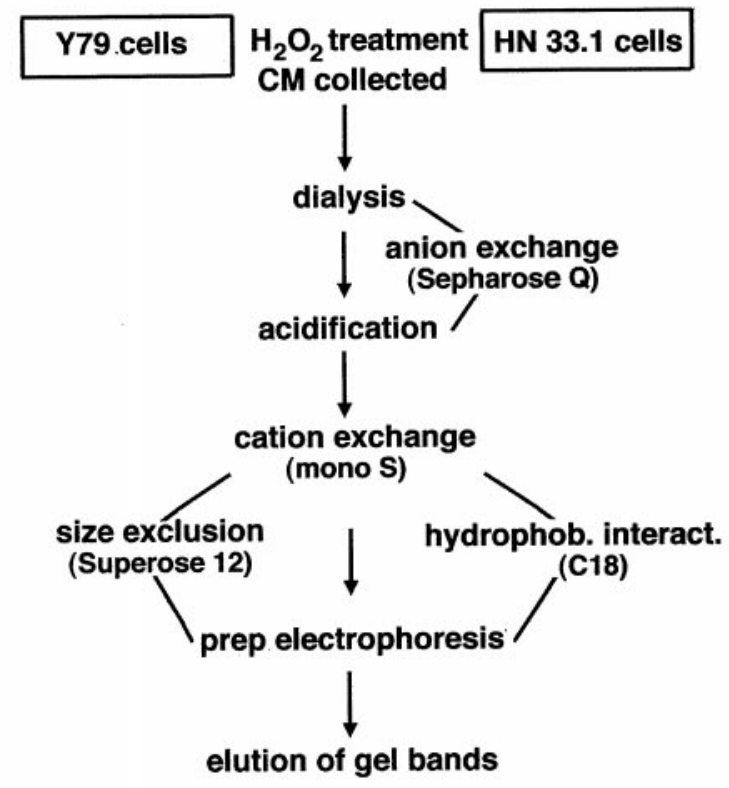

C.

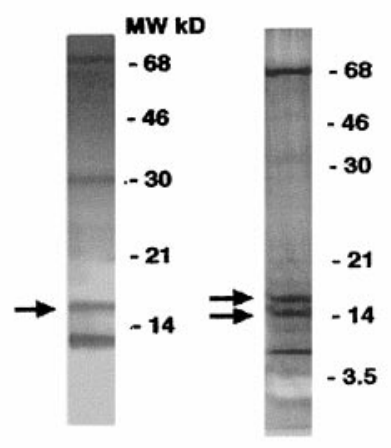

D.

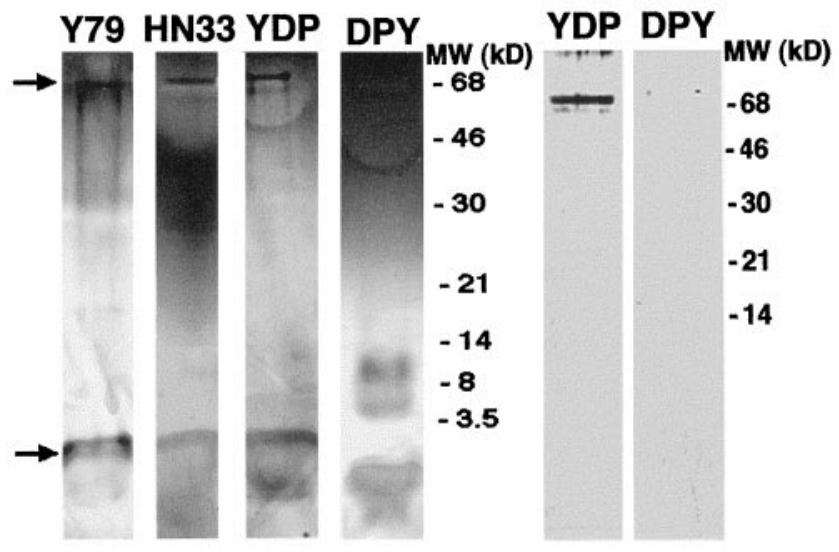

Figure 1. Highlights of purification of the survival-promoting peptide from medium conditioned by Y79 retinoblastoma and HN 33.1 cell lines (see Materials and Methods for further details). A, Flow chart showing the basic purification steps; modifications in the general procedure are shown for the different cell lines. Active fractions or gel bands were identified at various stages of the purification and after the preparative electrophoresis step (see Table 1). In $B$, a preparative gel from a HN 33.1 above, with the exception of positions 7 and 15, which were not assigned. A $3 \mathrm{kDa}$ band, which stains very poorly with both silver reagent and Coomassie blue, appears when the samples are treated with DTT, indicating that the higher molecular weight species are aggregates (Fig. 1D). However, no sequence was detected in the reduced bands of either preparation, suggesting the reduced peptide is recovered at levels too low for sequencing or has become N-terminal-blocked. A synthetic peptide (YDP), made on the basis of this sequence (see below), showed a $3 \mathrm{kDa}$ band with similar staining properties when run on gels under the same conditions. A more discrete band at $66-68 \mathrm{kDa}$ was also apparent in all the reduced samples, both purified and synthetic. This band appears to be a persistent aggregate of the smaller peptide. A second peptide (DPY), made by scrambling every three or four residues of this sequence, has a different pattern of mobility on SDS gels run under reducing conditions. It shows two or more low molecular bands between 3-6 kDa and a much less distinct aggregate near $66 \mathrm{kDa}$ (Fig. 1D).

\section{Synthetic peptide}

A 30 residue synthetic peptide was prepared based on the sequence obtained in the CM purifications. The sequence assignment for position 1 was ambiguous with the following most likely possibilities: Thr, Tyr, Pro, Val, Lys, and Ile. A Tyr was inserted because it occupies this position in a 13-residue fragment of an IgG-binding protein (Yoshizawa et al., 1992), which database alignments identified as having the highest homology to the first 13 residues of the Y79 peptide. Furthermore, the persistent aggregate band of the synthetic peptide was found to bind IgG after blotting to nitrocellulose (Fig. $1 D$, see also below).The cysteine was inserted in position 23 because unmodified cysteines were the most difficult amino acid to detect unambiguously with the sequencing methods used, and therefore the most likely residue at this position. Most importantly, at least two cysteines would be required in the peptide to explain the several aggregate bands that are dissociated with reducing reagents. In addition, it was observed that initial batches of the peptide contained Ser instead of Ala at position 20, a substitution that was later corrected. However, no apparent differences in biological activity were found because of this substitution. The scrambled peptide

CM purification is viewed in reflected light after staining with protein Quick Stain. In this purification, half of the starting material was collected from $\mathrm{H}_{2} \mathrm{O}_{2}$-treated cells and half from untreated cells $(U)$. Note diffuse gel band at $5-8 \mathrm{kDa}$. It is active in the in vitro assay and markedly exaggerated after treatment. $C$, Rerunning active gel bands on $10-20 \%$ gradient gels without reducing agents gave several additional aggregates for both Y79 and HN33.1 preparations. Samples were $\sim 3 \mu \mathrm{g}$ by BCA, and gels are stained with silver reagent. The peptide of interest in this study was identified by $\mathrm{N}$-terminal sequencing of bands in positions marked by arrows after these were transferred to PVDF membranes. $D$, Comparison of purified and synthetic peptides after running samples with reducing reagents. Aggregate bands of purified samples are diminished or absent in favor of a very poorly stained $3 \mathrm{kDa}$ band (arrow) that also appears when the synthetic $(Y D P)$ peptide is run under reducing conditions. A more discrete $66-68 \mathrm{kDa}$ band (arrow) is also found with all these samples and appears to represent a persistent aggregate of the peptide. Note that the scrambled peptide $(D P Y)$ gives a different pattern under the same conditions. Samples were estimated at $3 \mu \mathrm{g}$ protein for purified peptides and $10 \mu \mathrm{g}$ for synthetic peptides. Gels were stained with silver reagent. The lanes on the right are from a nitrocellulose blot of the synthetic peptides (20 $\mu \mathrm{g}$ each) run under reducing conditions before transfer. The blot was incubated with mouse $\operatorname{IgG}(2.5 \mu \mathrm{g} / \mathrm{ml})$ and then immunostained for IgG. The aggregate band of the YDP peptide binds to the IgG. 


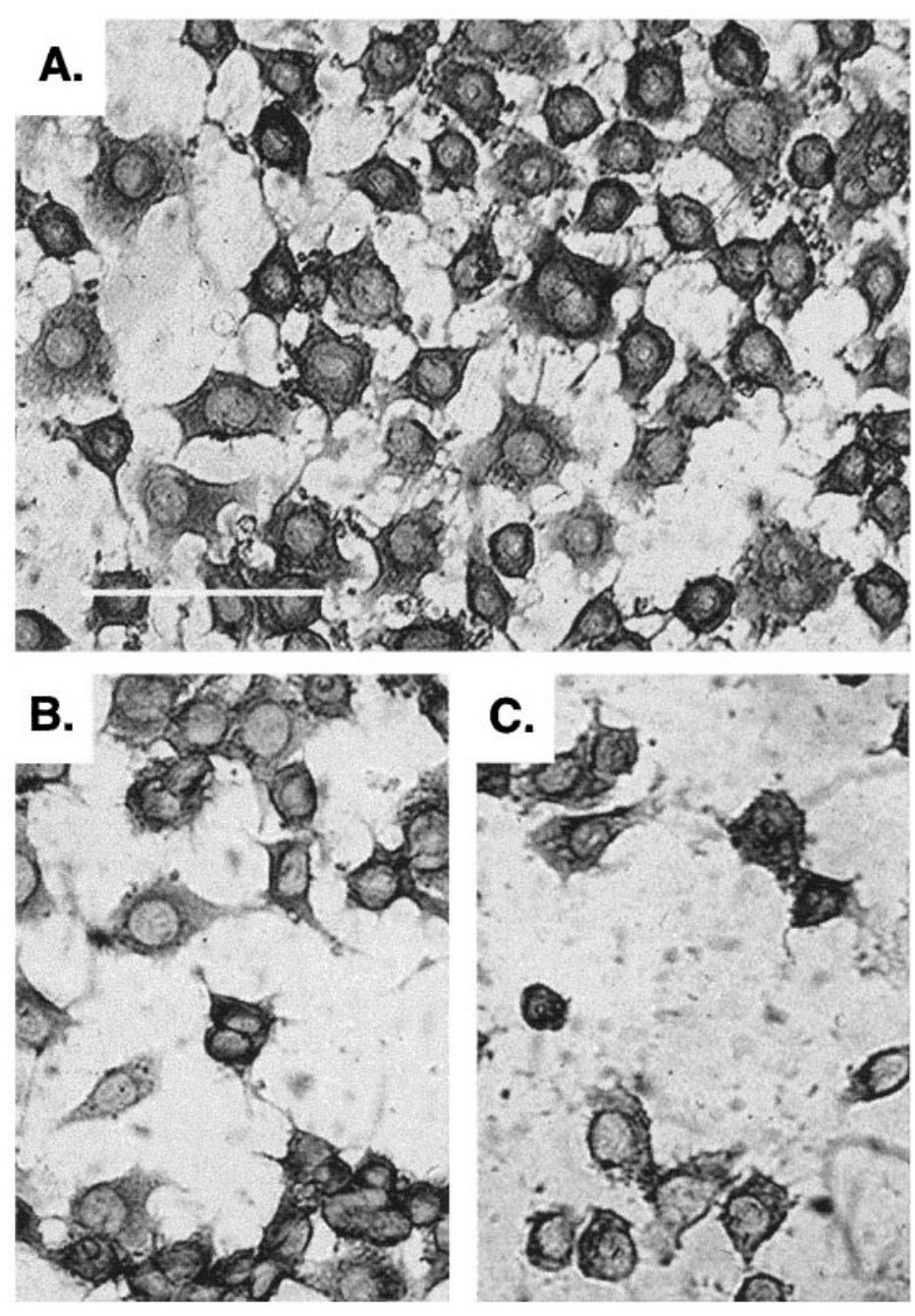

\section{Purified}

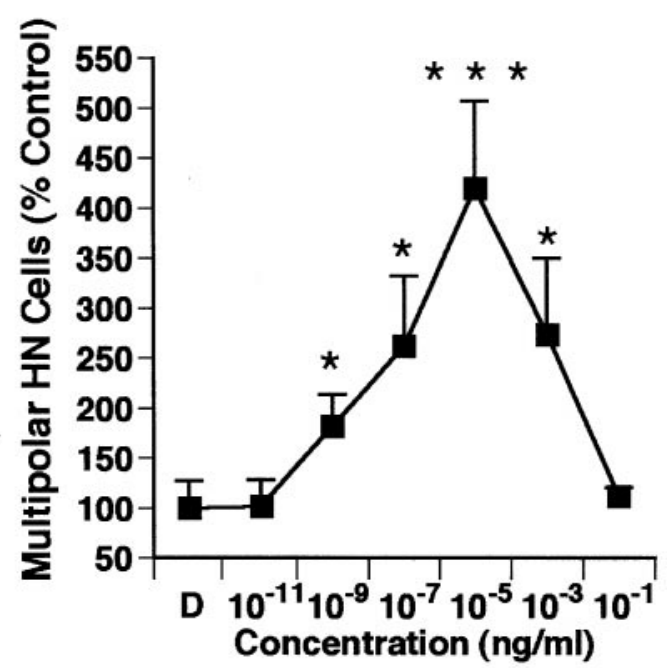

E. Synthetic

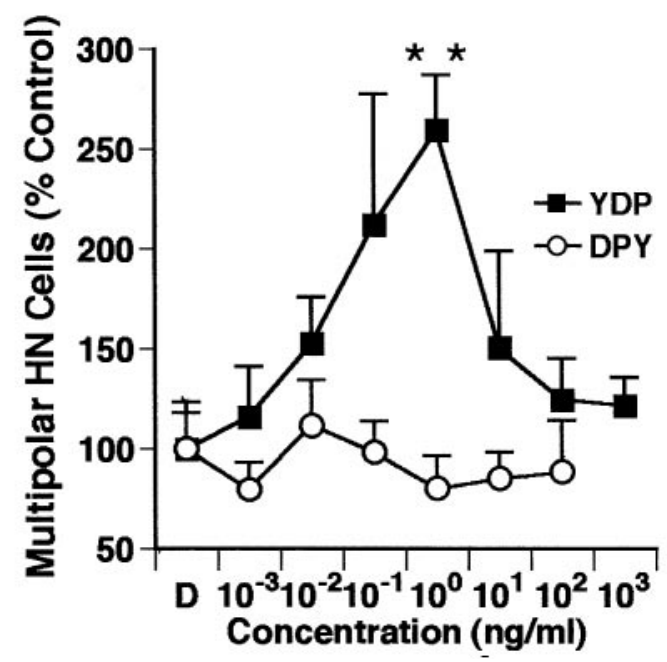

Figure 2. Survival assay with HN 33.1 cells. $A-C$ show $\mathrm{HN}$ cells immunostained for actin after they were subjected to two medium changes $(A)$ or two medium changes after $0.03 \% \mathrm{H}_{2} \mathrm{O}_{2}$ treatment for $15 \mathrm{~min}(B, C)$. The culture shown in $B$ received $1 \mathrm{ng} / \mathrm{ml}(0.33 \mathrm{~nm})$ of the synthetic peptide (diluted in DMEM) for the second change, whereas the one shown in $C$ received DMEM for both changes. Scale bar $A, 100 \mu \mathrm{m}$. $D$, Graph of survival of multipolar $\mathrm{HN} 33.1$ cells after $\mathrm{H}_{2} \mathrm{O}_{2}$ treatment and medium changes in experiments in which the peptide was supplied at different concentrations. Surviving cells are expressed as a percentage of the DMEM control $(D)$. In this experiment, the peptide was purified from the HN 33.1 cells and supplied at seven different concentrations between $10^{-11}$ and $10^{-1} \mathrm{ng} / \mathrm{ml}$. E. Similar curve for synthetic peptide $(Y D P)$ tested between $10^{-3}$ and $10^{3} \mathrm{ng} / \mathrm{ml}$ peptide concentration. Also shown in this graph is the same experiment with different concentrations of scrambled peptide $(D P Y)$, which is ineffective in this assay ( $n=6$ for all conditions). Similar curves were obtained in replicate experiments except that the peak concentrations varied as outlined in Table 1. ${ }^{*} p<0.05,{ }^{*} p<0.01$, and ${ }^{* *} p<0.001$, when peptide treatments at designated concentrations are compared with DMEM controls.

made for control of some of the assays had the following sequence: Asp-Pro-Tyr-Ala-Glu Ala-Ala-Ser-Gly-Pro Asn-ProGly-Ser-Cys Ser-His-Glu-Ser-Ala Gln-Ala-Glu-Asn-Cys GlyAla-Asp-Pro-Glu.

\section{In vitro assay}

The survival assay used to identify the peptide at various stages of purification and after peptide synthesis consisted of two medium changes preceded by a $10-20$ min period of $0.03 \% \mathrm{H}_{2} \mathrm{O}_{2}$ treatment. The extra medium change was introduced because experiments with conditioned medium (data not shown) suggested that endogenous survival-promoting agents accumulated in the cul- tures shortly after peroxide treatment. A second medium change was therefore introduced to limit the effect of these substances (which may include the peptide). In cultures with the same medium changes but no $\mathrm{H}_{2} \mathrm{O}_{2}$, there was minimal cell loss and substantial preservation of cell processes (Fig. $2 A$ ). After treatment with peroxide, there was a rapid loss of $\mathrm{HN}$ cell processes and more gradual death and/or detachment of cells from the collagen substrate. After $4 \mathrm{hr}$, most of the cells were clumped together, and lone cells were often shrunken and devoid of processes (Fig. 2C). In some experiments, treatment resulted in almost complete destruction of the cultures so that only a few clumps of surviving cells remained, and lone cells appeared lysed. 
However, in any given experiment the response of the cells was uniform, perhaps because the cells used to seed the microwells were all taken from the same large culture dish and so were developmentally similar. Regardless of the condition of the cultures when they were terminated, the effect of appropriate concentrations of peptide was to increase the number of surviving $\mathrm{HN}$ cells with processes that were still attached to the well (Fig. 2B).

Peptide effects were concentration-dependent within the range of concentrations tested in these experiments. Examples of concentration curves for the HN-purified peptide and the synthetic peptide are shown in Figure 2, $E$ and $D$, respectively. Also shown in Figure $2 E$ is a dose-response curve for the scrambled peptide. The scrambled peptide was not different from DMEM controls at any of the concentrations tested. These concentration curves could always be represented on a log scale; finer gradations were not generally tried. The variability encountered in the optimal effective concentrations at various stages of purification and after peptide synthesis is reported in Table 1 .

\section{In vivo assay}

\section{Lesions}

The lesions were centered on area 2 in the dorsal-lateral portion of both hemispheres. They measured $3-5 \mathrm{~mm}$ in diameter after $7 \mathrm{~d}$ survival. The white matter was involved at some level in all rats. We made several different measurements of surviving tissue to control for lesion size (see Materials and Methods), because estimates based simply on cavity size were subject to serious processing artifacts. As expected, these measurements revealed a range of lesion sizes that overlapped in all groups of rats. There was a trend toward smaller lesions in the peptide-treated hemisphere compared with the vehicle-treated hemisphere in peptidetreated rats, but these differences failed to reach statistical significance. The peptide-treated rats did have smaller lesions than those found in control rats (vehicle-treated on both sides) in terms of two of the measurements, i.e., the area of the lateral surviving segment of the hemisphere $(18 \%, p<0.03)$ and depth $(19 \%, p<$ 0.01 ). However, regression analyses (lesion measurement vs cell or process count) failed to reveal a relationship between these lesion parameters (or any of the others) and the counts of immune and neuronal cells or their process. Rather, the counts were consistently correlated with the presence or absence of peptide. Nevertheless, we limited our analysis to the medial surviving segment of the cortex (Fig. 3, low power micrographs), which showed the least differences in any group of rats or in any experimental condition.

\section{IgG immunoreactivity}

Peptide treatment increased IgG immunoreactivity in the medial surviving segment of the cortex (Fig. 3). Rats treated with $200 \mu \mathrm{M}$ peptide always showed bilateral increases in immunoreactivity compared with controls or normal rats. Animals that received 100 $\mu \mathrm{M}$ peptide also showed bilateral increases in immunoreactivity but usually showed some evidence of asymmetry favoring the treated hemisphere. This asymmetry is seen more clearly several hundred microns medial to the lesion in cortical area 3 (Fig. $3 D, E)$, in which clumps of immunoreactive material are often found adjacent to pyramidal cells. Untreated control rats did show a rim of IgG immunostaining around the edge of the lesions after a week, but not the denser accumulations in the parenchyma that are found in the treated animals.

The quantitative measures described below were for the most part consistent with this pattern of $\mathrm{IgG}$ immunoreactivity, which indicates that the effects of peptide treatment may be bilateral, and at the same time, that these effects are consistently biased toward the peptide-treated hemisphere. Therefore, IgG immunoreactivity may be indicative of peptide diffusion because the peptide binds IgG (Fig. 1D).

\section{Observations and quantification from sections stained by Nissl method}

The medial surviving segment of the cortex contains (from lesion edge to midline) a portion of surviving area 2, area 3 and 4, and caudal area 8 at the crest of the medial border of the hemisphere (Kreig, 1946; Haun and Cunningham, 1993). These are cytoarchitectonically distinct regions in Nissl-stained sections, all with a rich collection of pyramidal cells in layers III and V. Even with considerable shrinkage at the edges of the lesion, area 2 could still be distinguished by a distinct granular layer that continued into cortical area 3 more medially. These laminae were intact directly adjacent to the lesion in several of the peptide-treated animals, but this was not a consistent finding, because at least some sections in all brains contained collapsed darkly stained cells. It was not clear if these changes were attributable to the lesions or if they were artifacts caused by processing (in support of the latter, see Fig. 6, which shows examples of relatively intact cells immunostained for MAP2 at the lesion margins of treated rats). Because of this variability, we quantified cell areas at the medial margin of cortical area 3 just medial to area 2. This region was $\sim 500 \mu \mathrm{m}$ from the medial margin of the lesion. Here shrinkage of cells was also observed, but the cells were not hyperchromatic or generally collapsed as at the margins. In addition, this area can be defined readily because it forms a sharp boundary with area 4 medially (where the granular layer became much less distinct) and because of the very large pyramidal cells that occupy layer $\mathrm{Vb}$ in area 3 (Fig. 4; see Krieg, 1946).

In rats treated with $100 \mu \mathrm{M}$ peptide, the average cross-sectional areas of pyramidal-shaped cells in pyramidal layer $\mathrm{Vb}$ of this area were larger in the peptide-treated hemisphere compared with the opposite vehicle-treated hemisphere (Figs. 4, 5). When the areas of cells were divided arbitrarily into two groups, these data suggested this difference was attributable to a loss of large cells and an increase in small cells (Fig. 5). Control rats treated with vehicle on both sides had even greater shrinkage of cells in area 3 (Figs. 4, 5) when compared with either side of peptide-treated rats. Although we counted only pyramidal-shaped cells with an apical processes, the increases in small cells in vehicle-treated hemispheres may also be related to gliosis or invasion of immune cells. (see below). The rats treated with $200 \mu \mathrm{M}$ peptide showed the same general pattern, except the differences between the two sides was less striking. Furthermore, at both dosages it was apparent that vehicle-treated hemispheres of peptide-treated rats had more typical pyramidal cells of normal size than control rats that were treated with vehicle on both sides, another indication of the bilateral effects of peptide treatment (Figs. 4, 5; see also below).

\section{MAP2 immunocytochemistry}

MAP2 immunostaining was also applied to these rats because its pattern of expression is a sensitive indicator of neuronal damage (Kitagawa et al., 1989; Bigot and Hunt, 1990; Bigot et al., 1991; Matesic and Lin, 1994; Book et al., 1996). The lesions resulted in a loss of organized MAP2 immunoreactivity in the cerebral cortex, especially within dendrites. The effect of the peptide was to preserve MAP2+ cells and processes. In vehicle-treated hemi- 
A.
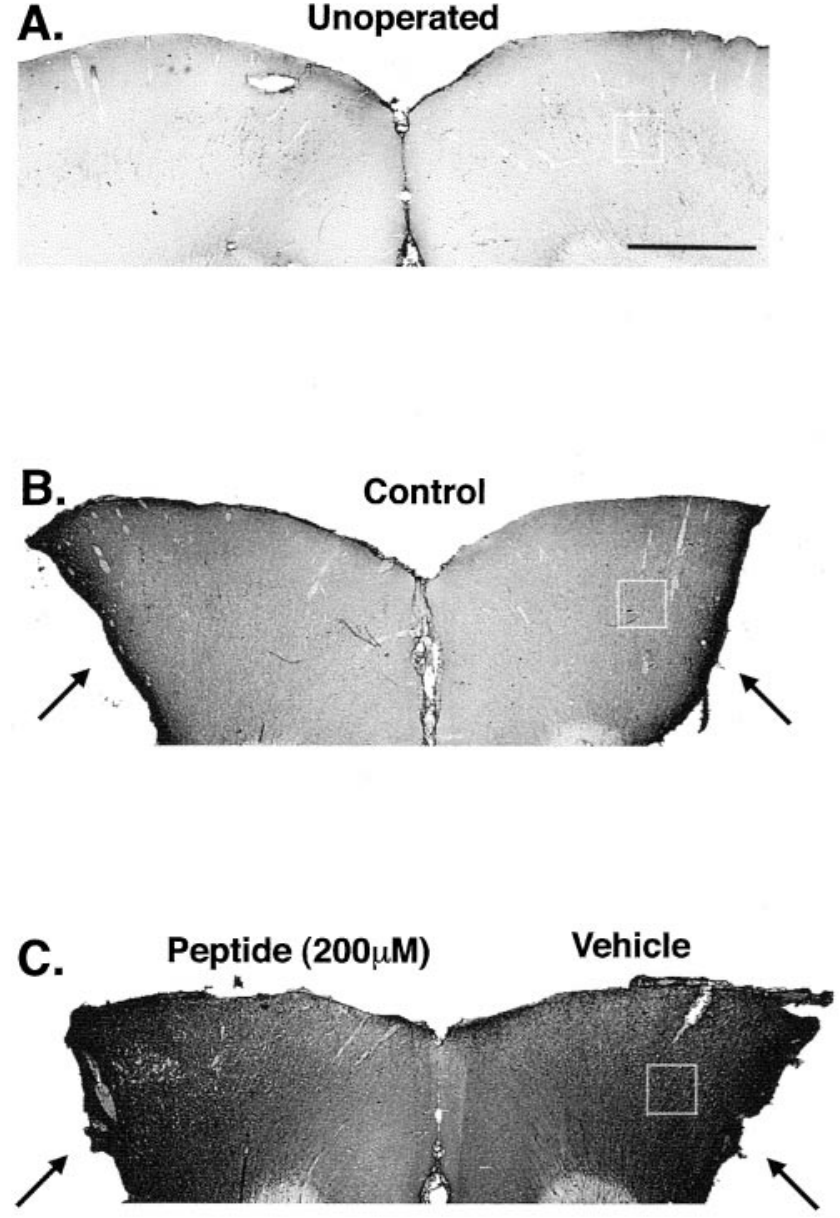

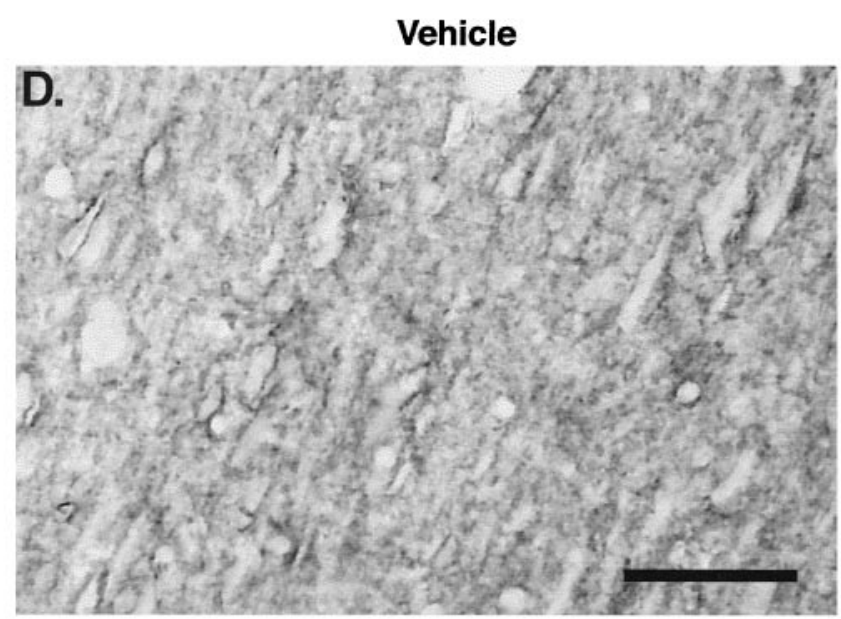

Peptide $(100 \mu \mathrm{M})$

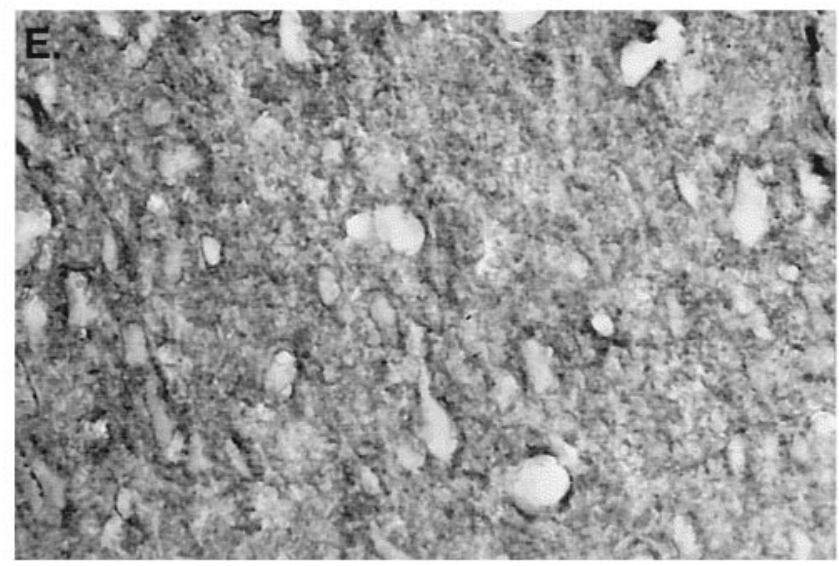

Figure 3. Increased IgG immunoreactivity after peptide treatment. Micrographs show IgG immunoreactivity in medial surviving cortical segment on both sides of the brain in single sections of operated rats and similar region in an unoperated rat. For $A-C$, midline is shown, and edge of lesion cavity is lateral and marked with an arrow. $A$, Section from unoperated rat showing light background IgG immunoreactivity. $B$, Section from control rat (vehicle on both sides) with bilateral cortical lesion $7 \mathrm{~d}$ earlier shows staining above background and dense staining at edge of lesion. $C$, Section of rat treated with $200 \mu \mathrm{M}$ peptide showing bilateral increase in IgG immunoreactivity. Scale bar, $1 \mathrm{~mm}$. $D$, Higher magnification of layer V of cortical area 3 in single section of rat treated with $100 \mu \mathrm{M}$ peptide. The peptide-treated cortex $(E)$ shows IgG aggregates outlining cortical pyramidal cells in layer $\mathrm{V}$, an effect much less apparent in the vehicle-treated hemisphere shown in $D$. There was a tendency for asymmetrical staining at the lower dosages of peptide. Scale bar, $50 \mu \mathrm{m}$. The boxes in $A-C$ show the region of cortical area 3 examined in $D$ and $E$ and in the quantitative analysis (see Figs. 4, 5).

spheres there was sometimes complete loss of immunoreactivity near the lesion, and in other cases complete or near complete disintegration of immunopositive cell bodies and dendrites. Surviving neurons near the lesion in these cases showed a reduction in the smooth and continuous primary dendrites, as well as loss of secondary and tertiary branches (Figs. 6,7). Figure 6 shows the two sides of a single section near the center of left and right lesion cavities in peptide-treated (Fig. 6A,B) and control (Fig. 6C) animals. In controls, there is both the complete loss (left panel) and the disintegration (right panel) of MAP2-immunopositive material. In the majority of peptide-treated rats, pyramidal neurons with at least intact secondary dendritic branches were found directly adjacent to the lesion, and approximately one-third show tertiary branches that were invariably involved in fine dendritic plexi (Fig. 7A). The data presented in Figures 6 and 7 show the bias we found toward the peptide-treated hemisphere of treated rats. Nevertheless, like the cell area measurements (see above), the effect of peptide treatment was found to be bilateral with this method, because total numbers of MAP2-immunopositive neurons (cell bodies with at least one dendrite) in the entire medial surviving segment were not different on the two sides of peptidetreated rats but were significantly increased when combined and compared with both sides of control rats (Fig. $7 B$ ).

\section{Microglia}

The microglia response after $7 \mathrm{~d}$ was inhibited by peptide treatment. In the vehicle-treated hemisphere and in control rats (vehicle on both sides), ramified ED-1-positive microglia were increased around the lesions after 1 week, consistent with previous studies (Milligan et al., 1991). The response was maximal in these control hemispheres in the white matter and overlying deep cortical layers at the medial margin of the lesion cavity. Counts of ramified microglia, immunostained for either ED-1 or IgG, were not statistically different between these various vehicle-treated hemispheres, although there was considerable variability when comparing numbers of ED-1-positive cells from different animals. Comparison within animals, and of the two sides of single sections (to minimize these methodological variations), revealed striking effects of peptide treatment on ED-1-immunopositive microglia in the peptide-treated hemispheres (Fig. 8). At some 
A.

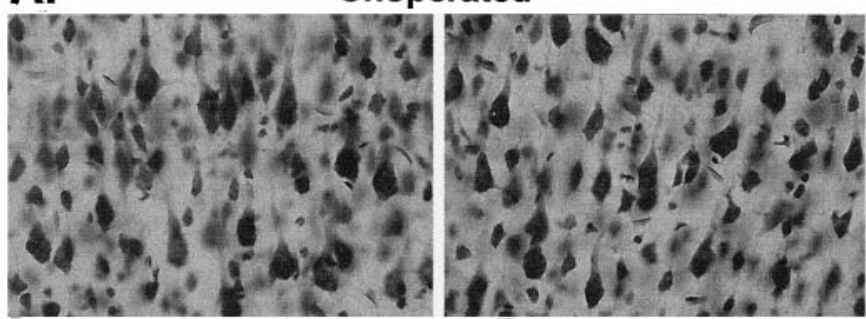

B.
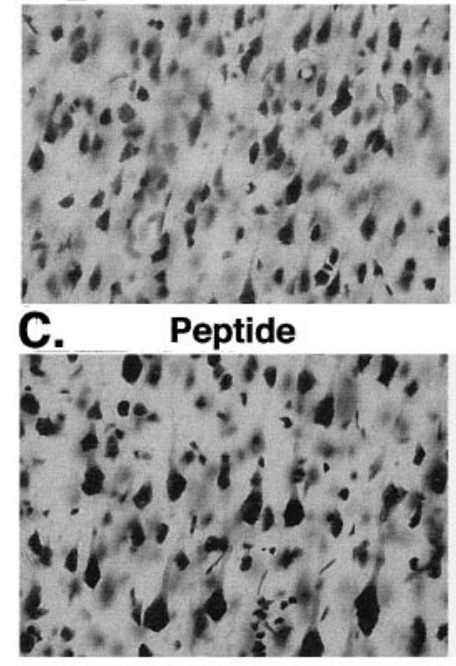

Control

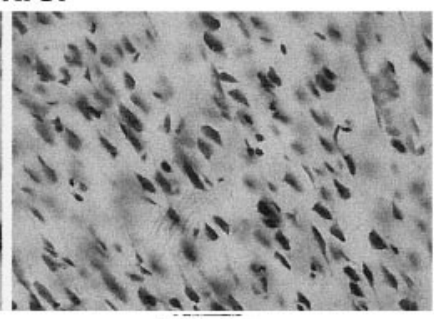

Vehicle

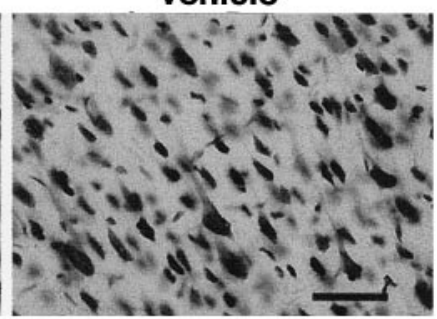

Figure 4. Nissl-stained sections of layer $\mathrm{Vb}$ of cortical area 3 showing preservation of large pyramidal cells after peptide treatment. $A$, Normal rat showing the pyramidal cells that characterize this region. Left and right sides are shown. $B$, Similar region as in $A$, but this micrograph shows left and right cortical area 3 in a control rat (vehicle on both sides). $C$, Rat treated with $100 \mu \mathrm{M}$ peptide. Many of the large cells were preserved after $7 \mathrm{~d}$, more in the left micrograph from the peptide-treated hemisphere. As shown in $C$ (and quantification in Fig. 5), vehicle-treated hemispheres in peptide-treated rats contain more pyramidal cells of normal size than in vehicle-treated control rats. Scale bar, $50 \mu \mathrm{m}$.

levels through the lesion, very few microglia were detected at the margins of the lesions after peptide treatment. Their overall density, counted on single sections at the same rostral-caudal level relative to the lesion, was reduced threefold in the peptidetreated hemispheres compared with vehicle-treated hemispheres. Animals treated with the synthetic peptide were processed for immunostaining with anti-rat $\mathrm{IgG}$, which also stained ramified microglia after the lesions. Although the total density of IgGpositive microglia was, on average, less than those immunostained for ED-1, the same level of reduction in microglia was found on the peptide-treated side. Once again there were very few of these cells detectable at some levels in the peptide-treated hemisphere. The IgG antibody occasionally reacted with larger cells and processes that may have been astrocytes, but these were not included in the counts.

\section{Hydrolysis of $p$-NPP}

Further analysis of the amino acid sequence led to the observation that residues $12-17$ of this peptide (Gly-Asp-Pro-Cys-HisGlu) resemble a motif found in several phosphatases. Because the cell survival and immune effects were also consistent with phosphatase activity (see Discussion), we investigated this possibility

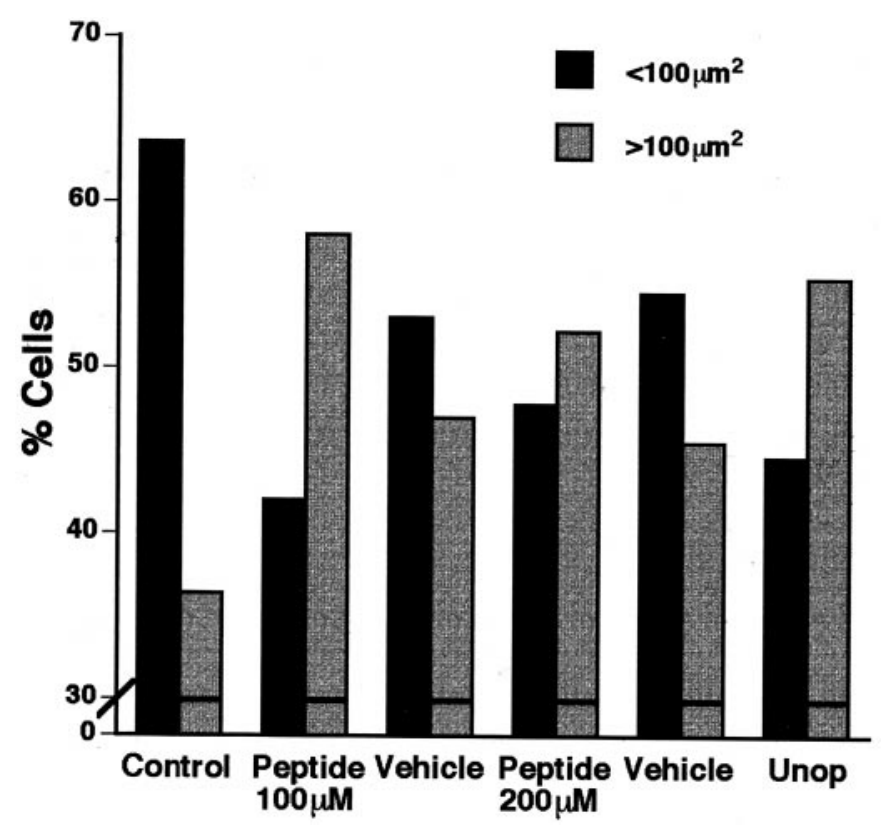

Figure 5. Preservation of pyramidal cell areas with peptide treatment. Plots of small $\left(<100 \mu \mathrm{m}^{2}\right)$ and large $\left(>100 \mu \mathrm{m}^{2}\right)$ cells in layer $\mathrm{Vb}$ of cortical area 3 of control rats with lesions (vehicle on both sides), peptidetreated rats (peptide and vehicle-treated sides of the brain at the two concentrations of peptide used), and unoperated normal rats. Because there were no left-right differences in either the control or the unoperated rats, these values were combined. The graphs indicate that the lesion results in a loss of large cells and increase in small cells, an effect that is reversed by $100 \mu \mathrm{M}$ peptide treatment, in which these proportions are normal. The average cell sizes between peptide-treated sides and vehicletreated sides of the brain in this group was significant (YDP $=153.4 \pm 23$ $\mu \mathrm{m}^{2}, n=8$; vehicle $\left.118.75 \pm 10 \mu \mathrm{m}^{2}, n=8 ; p<0.05\right)$, although comparisons with controls also suggest bilateral effects of treatment. Average cell size in hemispheres of five control rats was substantially smaller $\left(89.1 \pm 11.04 \mu \mathrm{m}^{2}, n=10, p<0.05\right)$ than in any hemisphere of the treated rats. Rats that received $200 \mu \mathrm{M}$ peptide show a similar pattern, but difference between two sides was not significant. The values for three unoperated rats were $141.5 \pm 4.72 \mu \mathrm{m}^{2}(n=6)$, not different from peptide-treated hemispheres.

with $p$-NPP, a common experimental substrate for a variety of phosphatases. The reaction conditions we used were similar to those used for several of these, especially calcineurin and related enzymes, in which dependency on Mn ions and inhibition by vanadate have been demonstrated (Gupta et al., 1990; Hengge and Martin, 1997). Figure 9 shows several experiments in which the catalytic activity of $5 \mu \mathrm{M}$ peptide was demonstrated in the presence of $3 \mathrm{~mm} \mathrm{Mn}{ }^{2+}$ and $1 \mathrm{mM} \mathrm{Zn}^{2+}$ for reactions lasting 60 min. Under these conditions, there was no catalytic effect of $1 \mu \mathrm{M}$ peptide with $1 \mathrm{~mm}$ substrate, but there was a clear requirement for $\mathrm{Mn}$ ions (Fig. 9A). In the latter experiments, $3 \mathrm{mM} \mathrm{Mn}^{2+}$ was omitted, and levels of $\mathrm{Zn}^{2+}$ were increased from 1 to $4 \mathrm{~mm}$. As a result, the catalytic reaction failed to proceed. The same result was obtained with the usual $1 \mathrm{~mm} \mathrm{Zn}$ but with $\mathrm{Mn}$ replaced with either $\mathrm{Ca}$ or $\mathrm{Mg}$ ions. There was also some inhibition of baseline hydrolysis of the substrate (i.e., in the absence of peptide) under these conditions. The reaction was also inhibited by including 30 $\mu \mathrm{M}$ vanadate in the reaction buffer (Fig. 9B). This inhibition was observed at both early and late phases of the reaction but was most pronounced for the latter, a pattern that may indicate a lack of turnover of transition state complexes. This result is consistent with the suggestion that vanadate inhibits phosphatase activity by 


\section{A. Peptide}

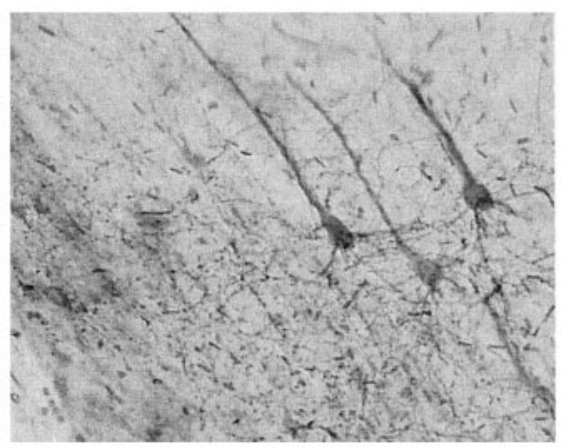

\section{B. Peptide}
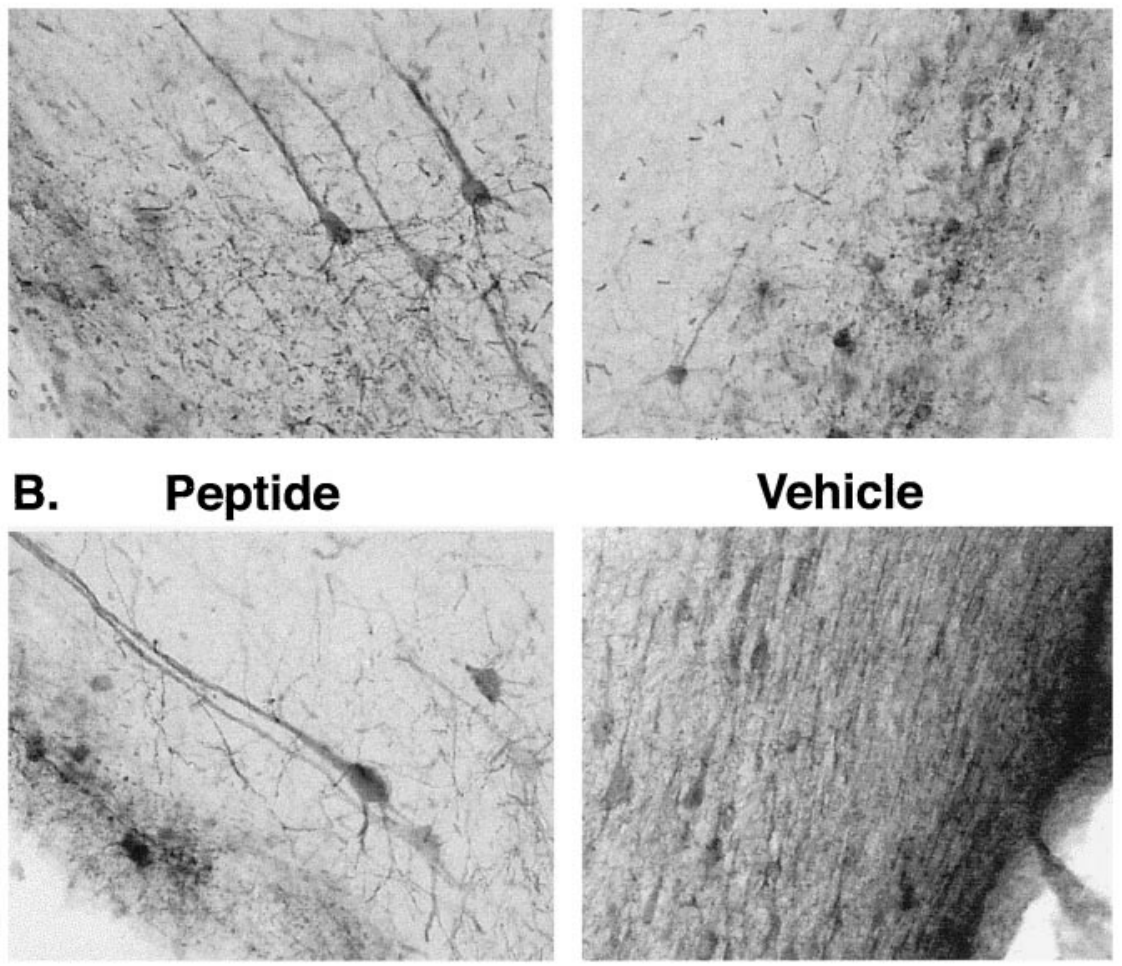

\section{Vehicle}

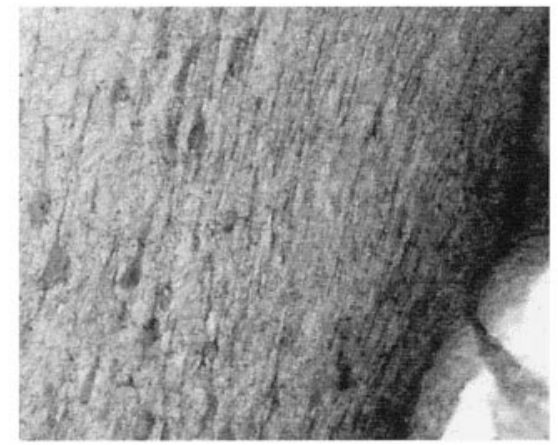

\section{C.}

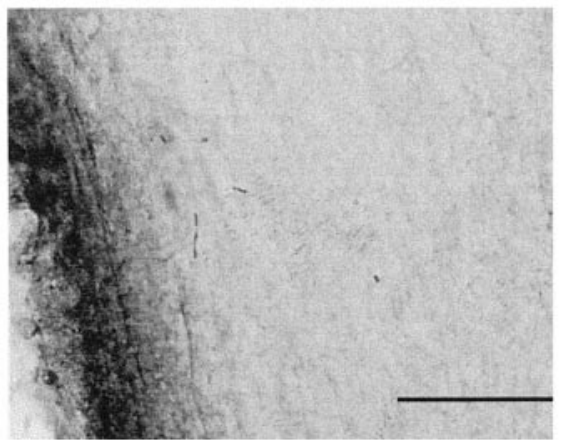

\section{Control}

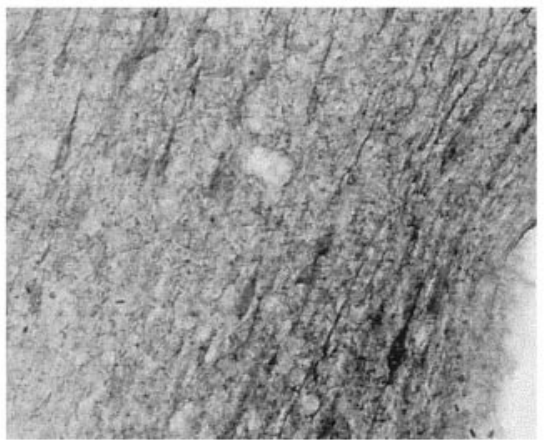

Figure 6. Preservation of MAP2-immunopositive neurons and dendrites in cortical layer $\mathrm{V}$ after peptide treatment. The micrographs are from the medial margins of lesions in surviving cortical area 2. They show left and right sides of single sections from different rats and each contains the lesion edge. $A$ and $B$ are from treated rats and show the greater preservation of neuronal structure in the peptide-treated hemisphere at this level than in the vehicle-treated hemisphere. $C$ is from a control rat that received vehicle in both hemispheres and shows both absence of MAP2 immunostaining and disintegrated MAP2+ profiles in a single section. Scale bar, $100 \mu \mathrm{m}$. forming a stable transition state analog (Zhang et al., 1997). Finally, the reaction is attenuated when $5 \mu \mathrm{M}$ the scrambled peptide is used (Fig. 9C). The fact that there is some activity with the scrambled peptide may be the result of inadvertent retention of some aspect of the critical catalytic site organization suggested to be responsible for these effects (see Discussion).

\section{DISCUSSION}

The results of this study suggest that agents that affect cell survival are available in cultures of Y79 and HN 33.1 cell lines shortly after oxidative challenge with hydrogen peroxide. A survival-promoting peptide, whose levels are exaggerated after treatment with $\mathrm{H}_{2} \mathrm{O}_{2}$, is recovered from SDS gels that are prepared after chromatography of medium conditioned by these cells. A biologically active synthetic peptide has been designed on the basis of sequences obtained during purification and has several properties that are similar to the purified peptides. Confirmation of the origin of the purified peptide as a product of these cell lines (and a natural participant in their response to oxidative stress) will require additional experiments, including identification and cloning of the nucleotides responsible for its production. Nevertheless, this study suggests: (1) a molecule similar to the synthetic peptide survives and is increased during oxidative stress, (2) the peptide promotes cell survival and process maintenance by diffusion in vitro and in vivo, and (3) the peptide binds IgG and demonstrates phosphatase activity, properties that are important for its biological effects.

The composition of the synthetic peptide is based primarily on sequences obtained during purification and to a lesser extent on alignments to that sequence available in the protein database in the BLAST network. Statistical significance is provided with these alignments. Although there were no strong homologies to this peptide, these comparisons were useful in designating the $\mathrm{N}$ terminus of the synthetic molecule. Thus, the $\mathrm{N}$-terminal tyrosine was inserted on the basis of significant similarity $(p=0.008)$ with a fragment of a bacterial antigen purified from cultures of group 
A.

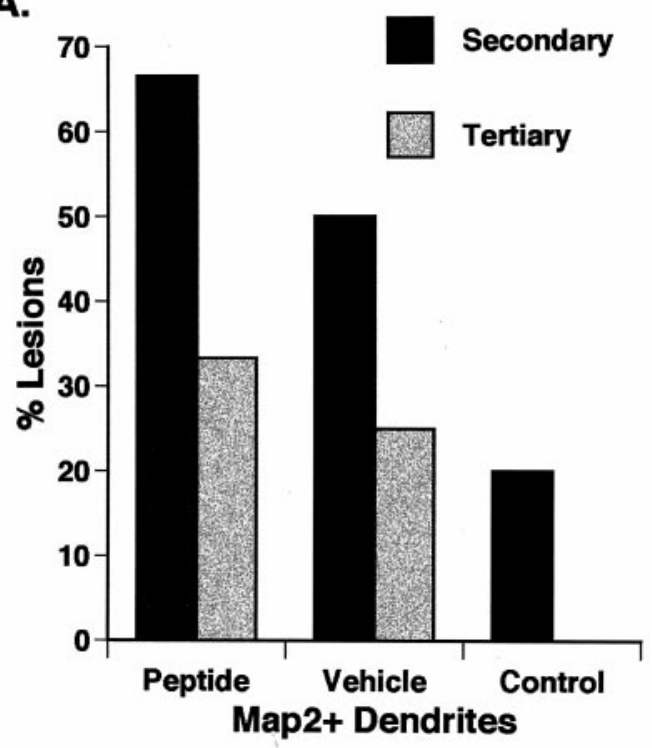

B.

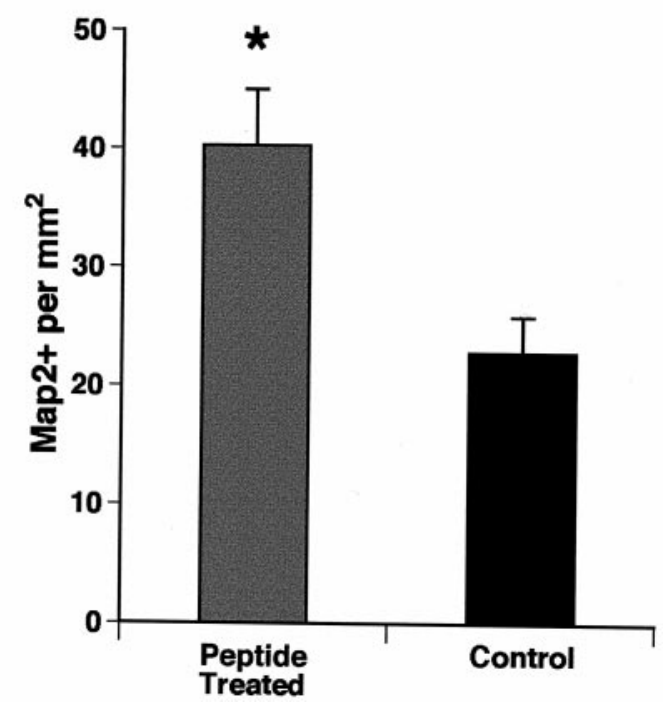

Figure 7. A, Frequency of lesions with preserved MAP2immunopositive neurons and dendrites in surviving cortical area 2 in peptide-treated and control rats. Frequencies were determined by scoring serial sections bilaterally through the entire lesion area. Although neurons with secondary dendritic branches appear on both sides of most of the peptide-treated rats, these are more frequent on the peptide-treated side of the brain. Tertiary dendrites (usually involved in basilar dendritic plexi, Fig. 6) appear in approximately one-third of the rats in the peptidetreated hemisphere, less in the vehicle-treated hemisphere, and none were found in the controls (vehicle on both sides). $B$, Bar graph showing density of MAP2+ cell bodies in treated animals versus controls in the entire medial surviving segment of the hemisphere. Counts from left and right hemispheres (peptide and vehicle-treated control) were combined for this comparison as were left and right sides of control rats. Peptide-treated, $40.2 \pm 4.6$ cells $/ \mathrm{mm}^{2}, n=24$; control, $22.8 \pm 3.0$ cells $/ \mathrm{mm}^{2} ; n=10 ;$ $p<0.05)$.

A $\beta$-hemolytic streptococci that were harvested from the pharynx of patients with acute poststreptococcal glomerulonephritis (Yoshizawa et al., 1992). This peptide is referred to as preabsorbing antigen, because it preabsorbs antisera that would normally react with tissue from these patients. It is suggested to be a part of a larger molecule that migrates with an apparent molecular weight of $43 \mathrm{kDa}$ on SDS gels, but this protein has not been fully characterized nor confirmed as bacterial in origin. The sequence of this peptide is: Tyr-Asp-Pro-Glu-Ala-Ala-Ser-Ala-Pro-GlyAsp-Gly-Asp. One potential concern is that the present results might be attributable to bacterial contamination of the cultures or impurities of similar origin in tissue culture reagents. However, the sequences, although related, are not identical. Furthermore, there are no other related sequences indicative of microorganisms. In addition, there were no signs of bacterial or fungal growth in the cultures that were treated with appropriate antibiotic and antimycotic agents (see Materials and Methods). Instead, this homology appears to be indicative of similar functional properties because Ig binding is also a property of the peptide identified in the present study. The other significant alignment of this peptide is with sequences contained within mouse neuroD2 ( $p=0.039)$, a member of the family of basic helix-loop-helix transcription factors (McCormick et al., 1996) that may function to promote maturation of neural precursors. These proteins have widespread expression in the nervous system, including a neuroblastoma cell line and in retina, predominantly in the photoreceptor layer of the latter (Yokoyama et al., 1996; Acharya et al., 1997). Thus, it is likely that members of this family also exist in the cell lines of the present study, although the significance of these particular sequences in the present peptide is not clear.

Further interesting comparisons, which are not detected with the standard alignment programs, may be found with sequence motifs of molecules that are functionally related to this peptide. One of these, Gly-Asn-His-Glu (or Asp) is identified by mutagenesis experiments as an important part of the catalytic region of several phosphatases of a family that includes calcineurin (Zhou et al., 1994; Mertz et al., 1997). The corresponding sequence in this peptide may be Gly-Asn-Pro-Cys-His-Glu, although it is unclear at present whether this part of the sequence is actually involved in the catalytic activity. Our experiments do show that the peptide is capable of phosphatase activity under experimental conditions that are similar to those required by several members of this family of phosphatases.

\section{Possible mechanisms of survival-promoting activity}

The peptide may operate by different mechanisms than those usually associated with the well known intracellular enzymes responsible for controlling the levels of reactive oxygen species or molecules suggested to subserve transient cellular adaptation to $\mathrm{H}_{2} \mathrm{O}_{2}$. In the first place, this peptide is available extracellularly and operates via diff usion. Second, both the means to produce the $\mathrm{CM}$ containing the peptide and the assay used to test it follow a much different time course than those in the studies in which transient adaptive responses are demonstrated. In both the preparative and in vitro testing parts of the present experiments, relatively high concentrations of $\mathrm{H}_{2} \mathrm{O}_{2}$ are applied for a short period. In the survival assay, cells show effects after only $4 \mathrm{hr}$ (or less) when the result of this treatment is the loss of cell processes along with variable degrees of death and detachment of the cells. The effect of the peptide is to increase viability as measured by numbers of multipolar $\mathrm{HN}$ cells with processes still attached to the collagen substratum. The studies of transient adaptation to $\mathrm{H}_{2} \mathrm{O}_{2}$ use much lower concentrations for a longer period and find a significant adaptive response at $18 \mathrm{hr}$, enough time for the synthesis of new proteins that may subserve the adaptive effects (Wiese et al., 1995). It is possible that the peptide identified in the 
A.
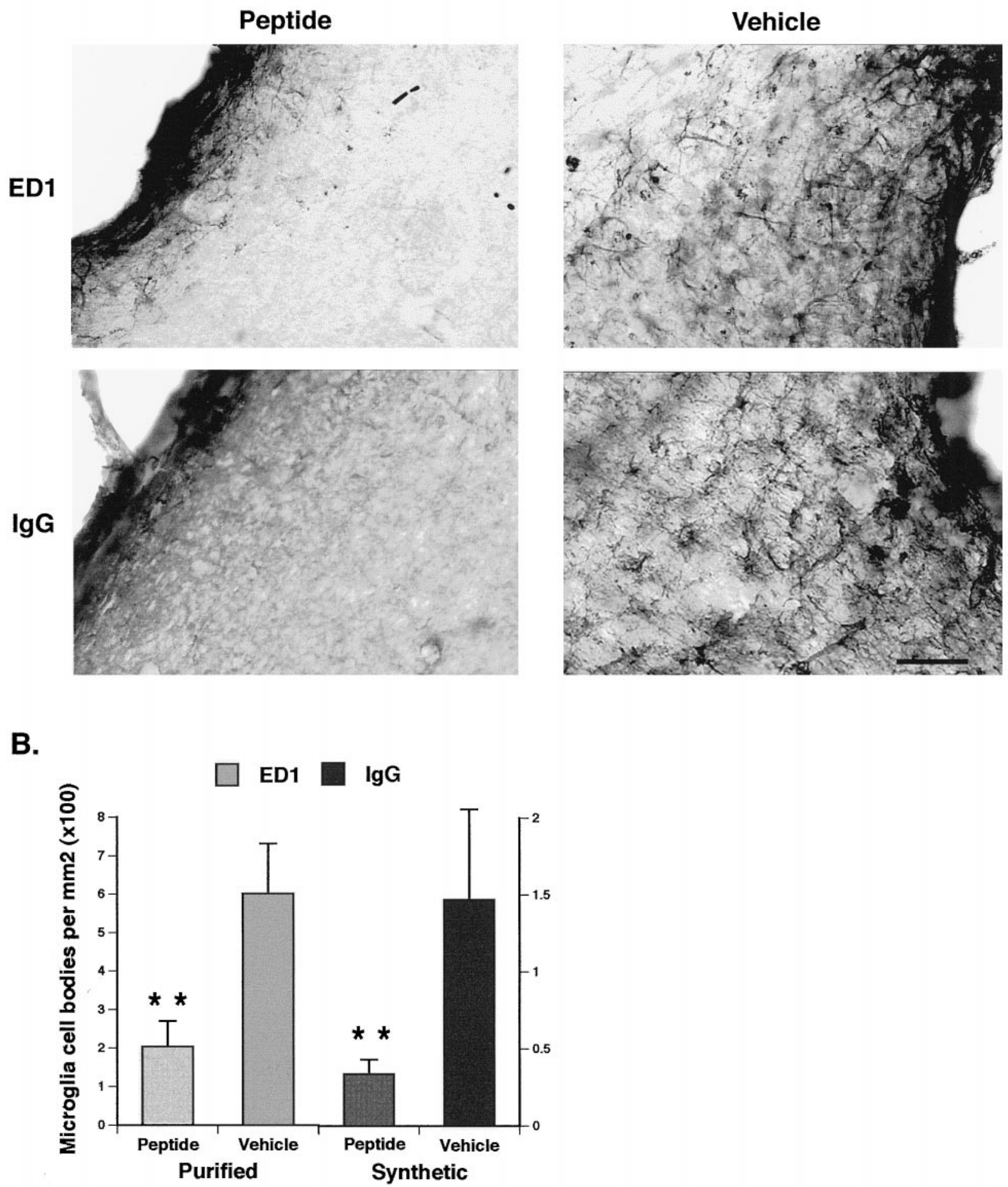

Figure 8. A, ED-1 and IgG-immunopositive microglia in peptide-treated and vehicle-treated hemispheres of rats with cortical lesions. The photomicrographs and the quantitative comparisons in $B$ are from the medial margin at the base of the lesions in the same tissue sections. These micrographs show the loss of microglia immunoreactivity around the lesion after treatment with peptide purified from CM of $\mathrm{HN} 33.1 \mathrm{cells}(E D-1)$ or the synthetic peptide $(I g G)$. Scale bar, $50 \mu \mathrm{m}$. B, Counts of microglia cell bodies in ED-1 and IgG-immunostained sections through the middle portion of the lesions. There was an average threefold decrease in the density of cells in the treated hemisphere. There were no differences between low and high-dose rats in this comparison. HN 33.1 CM-treated, $n=8$; YDP-treated, $n=12$. Statistical confidence levels are as described in Figure 3. 
A.

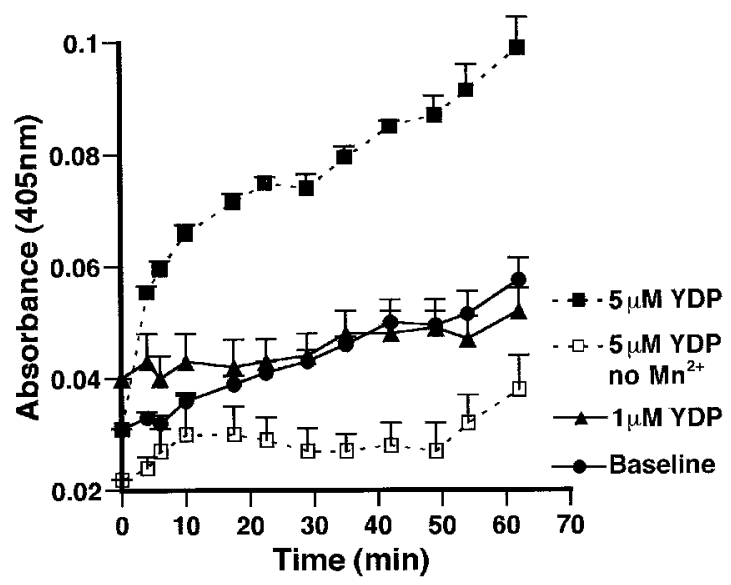

B.

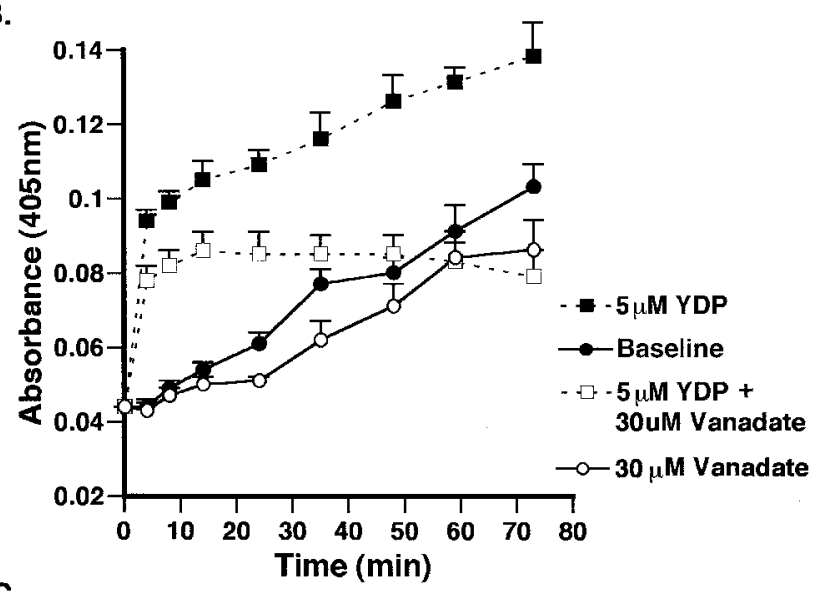

c.

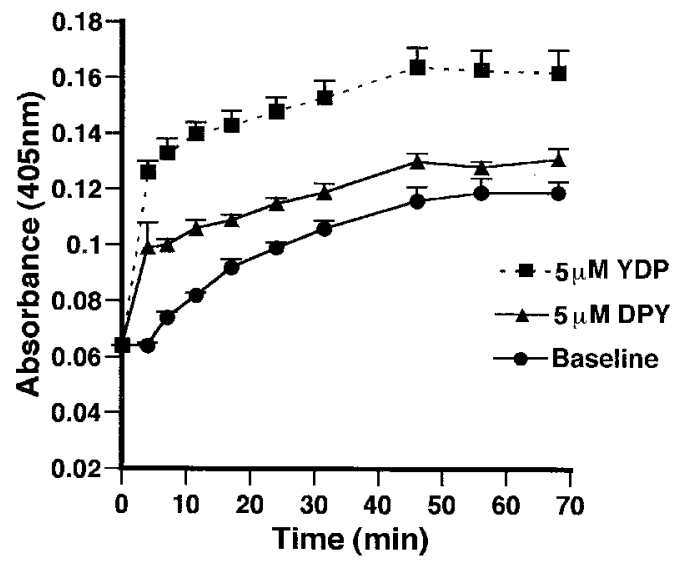

Figure 9. Catalytic activity of the survival-promoting peptide in the hydrolysis of $p$-NPP. In these experiments, $5 \mu \mathrm{M}$ the YDP peptide catalyzes dephosphorylation of $p$-NPP resulting in the production of nitrophenol, which absorbs at $405 \mathrm{~nm}$. This reaction is in presence of 1 $\mathrm{mM} \mathrm{Zn}{ }^{2+}$ and $3 \mathrm{mM} \mathrm{Mn}^{2+}$ and monitored for $1 \mathrm{hr}$ beginning at $4 \mathrm{~min}$. A rapid early phase and slower more protracted later phase (steady state) are apparent in the catalyzed reactions. $A$, Hydrolysis of $p$-NPP in the presence of 1 and $5 \mu \mathrm{M}$ YDP, and without $\mathrm{Mn}$ ions. In the latter experiments, $\mathrm{Mn}^{2+}$ is omitted from the reaction buffer, and $\mathrm{Zn}^{2+}$ is increased to $4 \mathrm{~mm}$. Similar inhibition was obtained using the usual $1 \mathrm{~mm}$ $\mathrm{Zn}^{2+}$ but replacing $\mathrm{Mn}^{2+}$ with $\mathrm{Ca}^{2+}$ or $\mathrm{Mg}^{2+} . B$, Inhibition of reaction with $30 \mu \mathrm{M}$ sodium orthovanadate. Vanadate inhibits mainly the steady state reaction under these conditions. $C$, Attenuated reaction with $5 \mu \mathrm{M}$ scrambled peptide $(D P Y)$. Concentrations of $p$-NPP were $1 \mathrm{~mm}(A)$ and $2 \mathrm{~mm}(B, C)$. Note the higher levels of both catalytic activity and autolysis with the higher substrate concentration. Each time point in the graphs represents the mean and SEM of absorbance values from four to eight different reaction wells for each condition. present study would also increase under the these milder conditions.

\section{Cell survival and the microglia response}

The microglial inhibition that is apparent after peptide treatment is likely to be of considerable importance to the survivalpromoting properties of the peptide after cortical lesions. The destructive effects of monocyte-derived cells after CNS lesions and in other models of nervous system degeneration are now generally recognized (for review, see Giulian, 1990, 1993; Moore and Thanos, 1996; McRae, 1997). The mechanisms that underlie the contributions of these cells to CNS damage are related directly or indirectly to the production of oxygen and nitrogen intermediates. In this and a previous study (Milligan et al., 1991), we found that microglia accumulate in the vicinity of cerebral cortex lesions in adult animals. The present data show that this response is inhibited after peptide treatment. There is a marked reduction in microglia near the lesion in the treated hemisphere. Interestingly, survival effects often extend to both sides in these same animals, which may indicate that other unseen participants in the immune response, residing in or near the lesion cavity, are inhibited bilaterally (e.g., macrophages, neutrophils, and cytotoxic T-cells; Feuerstein et al., 1997). Furthermore, the fact that certain dimensions of the lesions are consistently smaller in peptide-treated hemispheres may also be explained by inhibition of immune cell activity and the secondary damage that accompanies invasion of these cells.

The fact that there is an $\mathrm{IgG}$ response to the peptide and, at the same time, an inhibition of microglia is an interesting paradox. These cells should, by analogy with macrophages, accumulate in a typical immune response, either to the peptide (as an antigen) or because of the tissue damage (Kuby, 1997). The explanation may lie in the fact that the peptide is derived from tumor cell lines and has weak homology to a bacterial antigen. Part of the function of this molecule may therefore be related to immune evasion. Evasion mechanisms have been extensively studied in relation to viral and bacterial infections, as well as tumor growth (Falkow et al., 1992; Hellstrom et al., 1997). These cell types use several interesting tactics to avoid immune destruction, including the production of phosphatases to disable phagocytic cells (Bliska and Black, 1995). Our demonstration of phosphatase activity of the peptide and inhibition of the microglia response to lesions after peptide treatment are consistent with these observations. These results further suggest that immune evasion mechanisms might be exploited to promote anatomical repair after nervous system lesions or in other inflammatory disorders affecting the nervous system.

\section{Direct effects at the neuronal membrane}

The phosphatase activity of the peptide demonstrated in these experiments also raises the possibility that peptide application has direct protective effects on neurons by depressing responses mediated by the NMDA receptor. Glutamate toxicity and associated oxidative stress have long been recognized as destructive in a variety of neural degenerative disorders, including trauma (Choi, 1988; Simonian and Coyle, 1996). NMDA receptor blockade in such situations may be protective (Sanner et al., 1994), and it is now clear that phosphatases (calcineurin in particular) are involved in depression NMDA receptor activity (Tong et al., 1995; Torii et al., 1995; Oliet et al., 1997; Raman et al., 1996). Inhibition of calcineurin reverses the protective effects of NMDA receptor 
desensitization for cerebellar granule cells in vitro (Wood and Bristow, 1998). Although these experiments likely reflect intracellular activities of calcineurin or related molecules, the ultimate disposition of this peptide, which is applied extracellularly to lesions, is unknown. Furthermore, extracellular phosphorylation events at the cell membrane may also regulate long-term excitability changes (Fujii et al., 1995a,b; Torii et al., 1995). Thus, it possible that this peptide, which is derived from nervous system cell lines, promotes survival because it is targeted to substrates that will regulate potentially damaging levels of activity in neurons that are made vulnerable by lesions.

\section{REFERENCES}

Acharya HR, Dooley CM, Thoreson WB, Ahmad I (1997) cDNA cloning and expression analysis of NeuroD mRNA in human retina. Biochem Biophys Res Commun 233:459-463.

Altschul SF, Boguski MS, Gish W, Wootton JC (1994) Issues in searching molecular sequence databases. Nature Genet 6:119-129.

Beal MF (1995) Aging, energy and oxidative stress in neurodegenerative diseases. Ann Neurol 38:357-366.

Bigot D, Hunt SP (1990) Effect of excitatory amino acids on microtubule-associated proteins in cultured cortical and spinal neurones. Neurosci Lett 111:275-280.

Bigot D, Matus A, Hunt SP (1991) Reorganization of the cytoskeleton in rat neurons following stimulation with excitatory amino acids in vitro. Eur J Neurosci 3:551-558.

Bliska JB, Black DS (1995) Inhibition of the Fc receptor-mediated oxidative burst in macrophages by the Yersinia pseudotuberculosis tyrosine phosphatase. Infect Immun 63:681-685.

Book AA, Fischer I, Yu X-J, Iannuzzelli P, Murphy EH (1996) Altered expression of microtubule-associated proteins in cat trochlear motoneurons after peripheral and central lesions of the trochlear nerve. Exp Neurol 138:214-226.

Choi DW (1988) Glutamate neurotoxicity and diseases of the nervous system. Neuron 1:623-634.

Coyle JT, Puttfarcken P (1993) Oxidative stress, glutamate, and neurodegenerative disorders. Science 262:689-694.

Crawford DR, Davies KJ (1994) Adaptive response and oxidative stress. Environ Health Perspect 102:25-28.

Davies JM, Lowry CV, Davies KJ (1995) Transient adaptation to oxidative stress in yeast. Arch Biochem Biophys 317:1-6.

Davis JB (1996) Oxidative mechanisms in b-amyloid cytotoxicity. Neurodegeneration 5:441-444.

Dawson RMC, Elliot DC, Elliot WH, Jones KM (1986) Data for Biochemical Research, Ed 3, p 433. Oxford: Oxford Science.

Eagleson KL, Haun F, Cunningham TJ (1990) Different populations of dorsal lateral geniculate nucleus neurons have concentration-specific requirements for a cortically derived neuron survival factor. Exp Neurol 110:284-290.

Eagleson KL, Cunningham TJ, Haun F (1992) Rescue of both rapidly and slowly degenerating neurons in the dorsal lateral geniculate nucleus of adult rats by a cortically derived neuron survival factor. Exp Neurol 116:156-162.

Falkow S, Isberg RR, Portnoy DA (1992) The interaction of bacteria with mammalian cells. Annu Rev Cell Biol 8:333-363.

Feuerstein GZ, Wang X, Barone FC (1997) Inflammatory gene expression in cerebral ischemia and trauma. Potential new therapeutic targets. Ann NY Acad Sci 825:179-193.

Fujii S, Kato H, Furuse H, Ito K-I, Osada H, Hamaguchi T, Kuroda Y (1995a) The mechanism of ATP-induced long-term potentiation involves extracellular phosphorylation of membrane proteins in guineapig hippocampal CA1 neurons. Neurosci Lett 187:130-132.

Fujii S, Ito K-I, Osada H, Hamaguchi T, Kuroda Y, Kato H (1995b) Extracellular phosphorylation of membrane protein modifies theta burst-induced long-term potentiation in CA1 neurons of guinea-pig hippocampal slices. Neurosci Lett 187:133-136.

Furukawa K, Estus S, Weiming F, Mark RJ, Mattson MP (1997) Neuroprotective action of cycloheximide involves induction of Bcl-2 and antioxidant pathways. J Cell Biol 136:1137-1149.

Giulian D (1990) Microglia and tissue damage in the central nervous system. In: Differentiation and functions of glial cells (Levi G, ed), pp 379-389. New York: Alan Liss.
Giulian D (1993) Reactive glia as rivals in regulating neuronal survival. Glia 7:102-110.

Gotz ME, Kunig G, Riederer P, Youdim MBH (1994) Oxidative stress: free radical production in neural degeneration. Pharmacol Ther 63:37-122.

Greenlund LJS, Deckwerth TL, Johnson Jr EM (1995) Superoxide dismutase delays neuronal apoptosis: a role for reactive oxygen species in programmed neuronal death. Neuron 14:303-315.

Gupta RC, Khandelwal RL, Sulakhe PV (1990) Effects of sulfhydryl agents, trifluoperazine, phosphatase inhibitors and tryptic proteolysis on calcineurin isolated from bovine cerebral cortex. Mol Cell Biochem 97:43-52.

Haun F, Cunningham TJ (1993) Recovery of frontal cortex-mediated visual behaviors following neurotrophic rescue of axotomized neurons in medial frontal cortex. J Neurosci 13:614-622.

Hellstrom KE, Gladstone P, Hellstrom I (1997) Cancer vaccines: challenges and potential solutions. Mol Med Today 3:286-290.

Hengge AC, Martin BL (1997) Isotope effect studies on the calcineurin phosphoryl-transfer reaction: transition state structure and effect of calmodulin and $\mathrm{Mn}^{2+}$. Biochem 36:10185-10191.

Kitagawa K, Matsumoto M, Niinobe M, Mikoshiba K, Hata R, Ueda H, Handa N, Fukunaga R, Isaka Y, Kimura K, Kamada T (1989) Microtubule-associated protein 2 as a sensitive marker for cerebral ischemic damage: immunohistochemical investigation of dendritic damage. Neuroscience 31:401-411.

Krieg WJS (1946) Connections of the cerebral cortex. I. The albino rat. A. Topography of the cortical areas. J Comp Neurol 84:277-284.

Kuby J (1997) Immunology, p 370. New York: Freeman.

Lee HJ, Hammond DN, Large TH, Roback JD, Sim JA, Brown DA, Otten UH, Wainer BH (1990) Neuronal properties and trophic activities of immortalized hippocampal cells from embryonic and young adult mice. J Neurosci 10:1779-1787.

Mark RJ, Blanc EM, Mattson MP (1996) Amyloid b-peptide and oxidative cell injury in Alzheimer's disease. Mol Neurobiol 12:211-224.

Matesic DF, Lin RCS (1994) Microtubule-associated protein 2 as an early indicator of ischemia-induced neurodegeneration in the gerbil forebrain. J Neurochem 63:1012-1020.

Mattson MP, Cheng B, Smith-Swintosky VL (1993) Growth factormediated protection from excitotoxicity and disturbances in calcium and free radical metabolism. Semin Neurosci 5:295-307.

McCormick MB, Tamimi RM, Snider L, Asakura A, Bergstrom D, Tapscott SJ (1996) NeuroD2 and neuroD3: distinct expression patterns and transcriptional activation potentials within the neuroD gene family. Mol Cell Biol 16:5792-5800.

McRae A, Dahlstrom A, Ling EA (1997) Microglial in neurodegenerative disorders: emphasis on Alzheimer's disease. Gerontology 43:95-108.

Mertz P, Yu L, Rusnak F (1997) Kinetic and spectroscopic analyses of mutants of a conserved histidine in the metallophosphatases calcineurin and lamda protein phosphatase. J Biol Chem 272:21296-21302.

Milligan CE, Levitt P, Cunningham TJ (1991) Brain macrophages and microglia respond differently to lesions of the developing and adult visual system. J Comp Neurol 314:136-146.

Moore S, Thanos S (1996) The concept of microglia in relation to central nervous system disease and regeneration. In: Progress in neurobiology, Vol 48 (Kerkut GA, Phillis JW, eds), pp 441-460. Oxford: Elsevier.

Oliet SH, Malenka RC, Nicoll RA (1997) Two distinct forms of longterm depression coexist in CA1 hippocampal pyramidal cells. Neuron 18:969-982.

Raman IM, Tong G, Jahr CE (1996) Beta adrenergic regulation of synaptic NMDA receptors by cAMP-dependent protein kinase. Neuron 16:415-421.

Reim DF, Speicher DW (1994) A method for high-performance sequence analysis using polyvinylidene difluoride membranes with a biphasic reaction column sequencer. Anal Biochem 216:213-222.

Sanner CA, Cunningham TJ, Goldberger ME (1994) NMDA receptor blockade rescues Clarke's and red nucleus neurons after spinal hemisection. J Neurosci 14:6472-6480.

Simonian NA, Coyle JT (1996) Oxidative stress in neurodegenerative diseases. Annu Rev Pharmacol Toxicol 36:83-106.

Tong G, Shepherd D, Jahr CE (1995) Synaptic desensitization of NMDA receptors by calcineurin. Science 267:1510-1512.

Torii N, Kamishita T, Otsu Y, Tsumoto T (1995) An inhibitor for cal- 
cineurin, F K506, blocks induction of long-term depression in rat visual cortex. Neurosci Lett 185:104.

Wiese AG, Pacifici RE, Davies KJ (1995) Transient adaptation of oxidative stress in mammalian cells. Arch Biochem Biophys 318:231-240.

Wood AM, Bristow DR (1998) $N$-methyl-D-aspartate receptor desensitisation is neuroprotective by inhibiting glutamate-induced apoptoticlike cell death. J Neurochem 70:677-687.

Yankner BA (1996) Mechanisms of neuronal degeneration in Alzheimer's disease. Neuron 16:921-932.

Yokoyama M, Nishi Y, Miyamoto Y, Nakamura M, Akiyama K, Matsubara K, Okubo K (1996) Molecular cloning of a human neuroD from a neuroblastoma cell line specifically expressed in the fetal brain and adult cerebellum. Mol Brain Res 42:135-139.

Yoshizawa N, Oshima S, Sagel I, Shimizu J, Treser G (1992) Role of a streptococcal antigen in the pathogenesis of acute poststreptococcal glomerulonephritis. J Immunol 148:3110-3116.

Zhang M, Zhou M, Van Etten RL, Stauffacher CV (1997) Crystal structure of bovine low molecular weight phosphotyrosyl phosphatase complexed with the transition state analog vanadate. Biochemistry 36:15-23.

Zhou S, Clemens JC, Stone RL, Dixon JE (1994) Mutational analysis of a Ser/Thr phosphatase. J Biol Chem 26234-26238. 